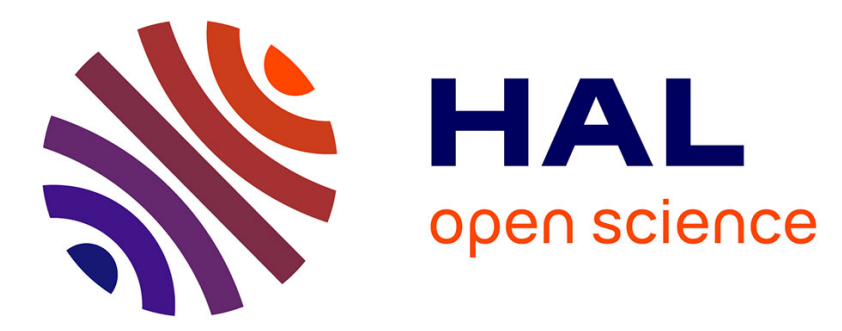

\title{
Syntheses of Natural and Biologically Relevant Products through Asymmetric Metal-Catalyzed Domino Reactions. A Review
}

Hélène Pellissier

\section{- To cite this version: \\ Hélène Pellissier. Syntheses of Natural and Biologically Relevant Products through Asymmetric Metal-Catalyzed Domino Reactions. A Review. Organic Preparations and Procedures International: The New Journal for Organic Synthesis, 2019, pp.311-344. 10.1080/00304948.2019.1590681 . hal- 02106065}

\section{HAL Id: hal-02106065 https://hal.science/hal-02106065}

Submitted on 22 Apr 2019

HAL is a multi-disciplinary open access archive for the deposit and dissemination of scientific research documents, whether they are published or not. The documents may come from teaching and research institutions in France or abroad, or from public or private research centers.
L'archive ouverte pluridisciplinaire HAL, est destinée au dépôt et à la diffusion de documents scientifiques de niveau recherche, publiés ou non, émanant des établissements d'enseignement et de recherche français ou étrangers, des laboratoires publics ou privés. 


\title{
Syntheses of Natural and Biologically Relevant Products through Asymmetric Metal-Catalyzed Domino Reactions. A Review
}

\author{
Hélène Pellissier \\ Aix Marseille Univ, CNRS, Centrale Marseille, iSm2, \\ Marseille, France
}

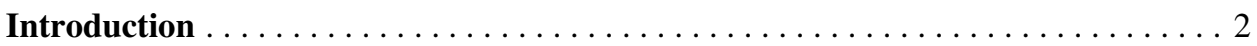

I. Syntheses Based on Palladium-Catalyzed Domino Reactions $\ldots \ldots \ldots \ldots 2$

1. Heck-Initiated Domino Reactions as Key Steps ...................

2. Wacker-Initiated Domino Reactions as Key Steps ..................6

3. Other Domino Reactions as Key Steps ...................... 12

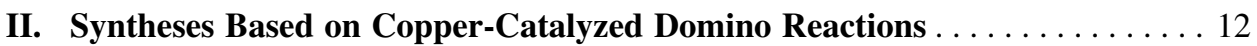

1. Michael-Initiated Domino Reactions as Key Steps ................12

2. Other Domino Reactions as Key Steps ........................ 17

III. Syntheses Based on Rhodium-Catalyzed Domino Reactions . . . . . . . . . . . 19

IV. Syntheses Based on Aluminum-Catalyzed Domino Reactions .......... 23

V. Syntheses Based on Domino Reactions Catalyzed by Other Metals . . . . . 2 25

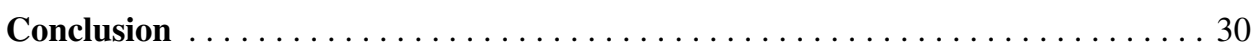

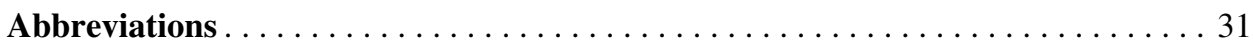

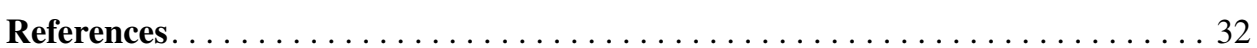




\title{
Syntheses of Natural and Biologically Relevant Products through Asymmetric Metal-Catalyzed Domino Reactions. A Review
}

\author{
Hélène Pellissier \\ Aix Marseille Univ, CNRS, Centrale Marseille, iSm2, Marseille, France
}

\section{Introduction}

A challenging goal in synthetic chemistry is the synthesis of complex products from simple starting materials by using one-step processes such as domino reactions. ${ }^{1-16} \mathrm{~A}$ domino reaction was defined by Tietze in 1993 as a reaction involving two or more bond-forming transformations, occurring under strictly the same reaction conditions without adding additional reagents and catalysts. ${ }^{17-20}$ These economic processes avoid costly protecting groups and time-consuming purification procedures after each step. In the last two decades, an impressive number of these powerful reactions have been developed, allowing the construction of very complex molecules in single steps from simple materials often with very high stereocontrol and yields. In most cases, remarkable enantioselectivities have been reported in reactions promoted by either chiral metal catalysts or organocatalysts. Especially, the considerable impact of the advent of asymmetric transition-metal catalysis has allowed the immense development of many highly efficient enantioselective metal-catalyzed domino reactions. The wide variety of these processes well reflects the variety of metals employed to promote them. This review collects for the first time the total syntheses of natural and biologically important products employing an enantioselective metal-catalyzed domino reaction as a key step, covering the years from 1996 to the present.

\section{Syntheses Based on Palladium-Catalyzed Domino Reactions}

\section{Heck-Initiated Domino Reactions as Key Steps}

Many syntheses of natural and bioactive products include as key steps asymmetric domino processes $^{21-27}$ initiated by a Heck reaction. ${ }^{28-30}$ As an early example, the first total synthesis of the naturally occurring pentacyclic polyketide $(+)$-xestoquinone was developed by Keay et al., in 1996. ${ }^{31}$ This compound exhibits important biological activities, such as antimalarial, antiproliferative and cardiotonic properties. The key step of this unprecedented synthesis was an asymmetric palladium-catalyzed domino intramolecular Heck/cyclization reaction of a functionalized naphthyl triflate. As shown in Scheme 1, the reaction was promoted in toluene at $110^{\circ} \mathrm{C}$ by a combination of $\mathrm{Pd}_{2}(\mathrm{dba})_{3}$ as precatalyst and $(S)$-BINAP as chiral ligand in the presence of pentamethylpiperidine (PMP). It afforded the corresponding key pentacyclic chiral intermediate in good yield (82\%); however, the enantioselectivity 


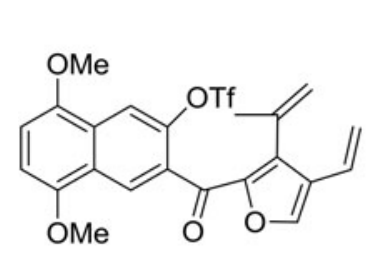

$\mathrm{Pd}_{2}(\mathrm{dba})_{3}(2.5 \mathrm{~mol} \%)$

(S)-BINAP (10 mol\%)

PMP (8 equiv)

toluene, $110^{\circ} \mathrm{C}$<smiles>COc1ccc(OC)c2cc3c(cc12)C(=O)c1occ2c1[C@]3(C)CC=C2</smiles>

$82 \%$ yield, $68 \%$ ee

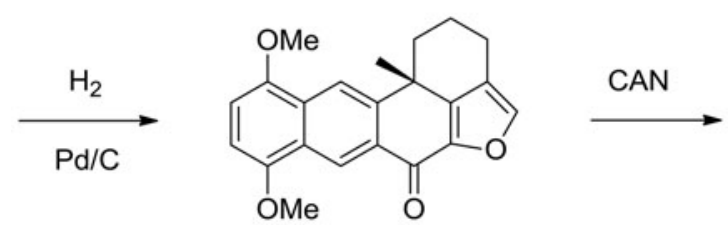

Scheme 1<smiles>C[C@]12CCCc3coc(c31)C(=O)c1cc3c(cc12)C(=O)C=CC3=O</smiles>

$(+)$-xestoquinone

\begin{abstract}
was only moderate $(68 \% e e)$. The latter was subsequently submitted to a catalytic hydrogenation on $\mathrm{Pd} / \mathrm{C}$ followed by oxidation with ceric ammonium nitrate (CAN) to give the final natural product (+)-xestoquinone (Scheme 1).

A possible mechanism for the key enantioselective palladium-catalyzed domino intramolecular Heck/cyclization reaction of the total synthesis of (+)-xestoquinone (Scheme 1) is proposed in Scheme 2. It involves a syn-addition insertion of a palladium complex on the $R e$-face of the vinyl group to give a pentacyclic palladium intermediate which is further submitted to a syn- $\beta$-elimination to afford the final domino product.

The same year, Shibasaki et al. applied a related methodology to synthesize the marine natural product (+)-halenaquinone, exhibiting antibiotic, cardiotonic and protein tyrosine kinase inhibitory activities. ${ }^{32,33}$ In this case, the key step of the synthesis was the enantioselective palladium-catalyzed domino intramolecular Heck/cyclization reaction of a bicyclic triflate performed at $60^{\circ} \mathrm{C}$ in THF as solvent in the presence of a chiral palladium catalyst generated in situ from $\mathrm{Pd}(\mathrm{OAc})_{2}$ and the chiral ligand $(S)$ BINAP mentioned above. It afforded the corresponding domino product in both high yield $(78 \%)$ and enantioselectivity $(87 \%$ ee), as shown in Scheme 3. The latter was further converted into the expected (+)-halenaquinone through fifteen supplementary steps which are detailed in Scheme 3. First, the domino product was converted into the corresponding alcohol through a two-step sequence. The further transformation of this alcohol into the corresponding triflate followed by reaction with a cyanohydrin triisopropylsilyl ether and then treatment with $\mathrm{NaF}$ provided the corresponding $\alpha, \beta$-acetylenic ketone. After protection of the carbonyl function of this compound as an acetal and that of the ethynyl functionality with a triisopropylsilyl group, the resulting compound was submitted to benzylic oxidation with DDQ to give the corresponding ketone. Then, successive treatments with $\mathrm{O}_{2}$ in the presence of tert-BuOK, NaI and $\mathrm{TsOH}$ afforded an $\alpha$-iodo enol. Subsequently, the latter underwent cyclization in the presence of $\mathrm{Pd}_{2}(\mathrm{dba})_{3}$ to give the corresponding pentacyclic compound which finally provided the anticipated (+)-halenaquinone through successive desilylation by treatment with tetrabutylammonium fluoride (TBAF) and CAN oxidation.
\end{abstract}




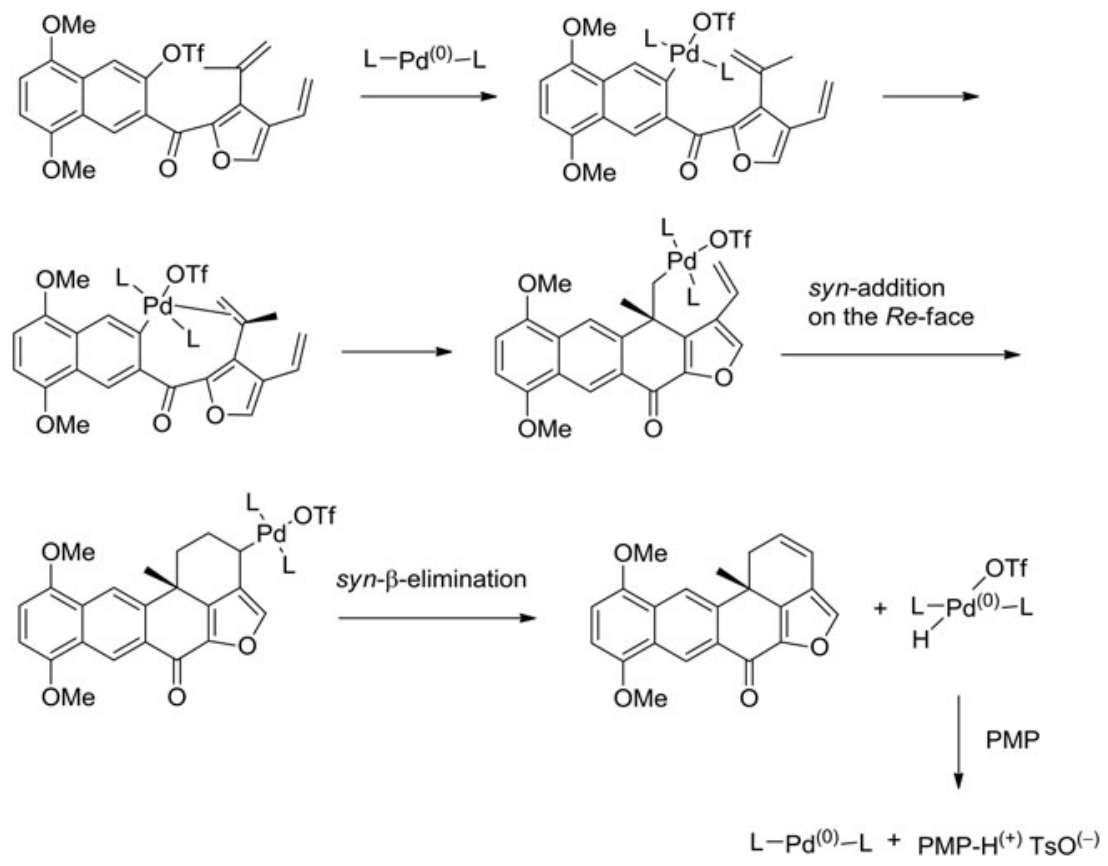

Scheme 2

Later in 2007, Zhu et al. developed another type of enantioselective palladium-catalyzed domino sequence initiated by a Heck reaction to be applied in a total synthesis of the naturally occurring butyryl-cholinesterase inhibitor (-)-physostigmine, which is employed for the treatment of glaucoma and Alzheimer's diseases. ${ }^{34}$ As shown in Scheme 4 , ortho-iodoanilidines reacted at $120^{\circ} \mathrm{C}$ in DMF as solvent with $\mathrm{K}_{4}\left[\mathrm{Fe}(\mathrm{CN})_{6}\right]$ through a domino intramolecular Heck/cyanation reaction in the presence of $\mathrm{Pd}(\mathrm{dba})_{2}$ as precatalyst and $(S)$-DIFLUORPHOS as chiral ligand. This one-pot process led to the corresponding chiral oxindoles in moderate to good yields (54-78\%) and enantioselectivities $(61-79 \% e e)$. The authors demonstrated that one of these products $\left(\mathrm{R}^{1}=\mathrm{OMe}\right.$, $\mathrm{R}^{2}=\mathrm{H}$ ) could be used as key intermediate in a total synthesis of (-)-physostigmine. As illustrated in Scheme 4, the reductive cyclization of this domino product with $\mathrm{LiAlH}_{4}$ led to the corresponding hexahydropyrroloindole which was subsequently submitted to $N$-methylation under reductive amination conditions to afford esermethole. Then, cleavage of the methoxy group of esermethole with $\mathrm{HBr}$ led to the corresponding phenol which was finally submitted to $\mathrm{NaH}$ in the presence of $N$-succinimidyl- $N$-methylcarbamate to give the expected (-)-physostigmine.

In 2015, the same authors also developed a total synthesis of the natural powerful inhibitor of acetyl-cholinesterase $(+)$-esermethole. ${ }^{35}$ It involved a chiral oxindole/azole bis-heterocycle as key intermediate which was generated through the first example of an asymmetric domino Heck/intermolecular arylation reaction. As shown in Scheme 5, the domino process between oxadiazoles and $N$-aryl acrylamides was promoted in acetonitrile at $80^{\circ} \mathrm{C}$ by a chiral palladium catalyst in situ generated from $\mathrm{PdCl}_{2}(\mathrm{MeCN})_{2}$ and a chiral Phox-type ligand in the presence of $N, N, N, N$-tetramethylguanidine (TMG) as base. The formed chiral domino bicyclic products bearing a quaternary stereocenter 


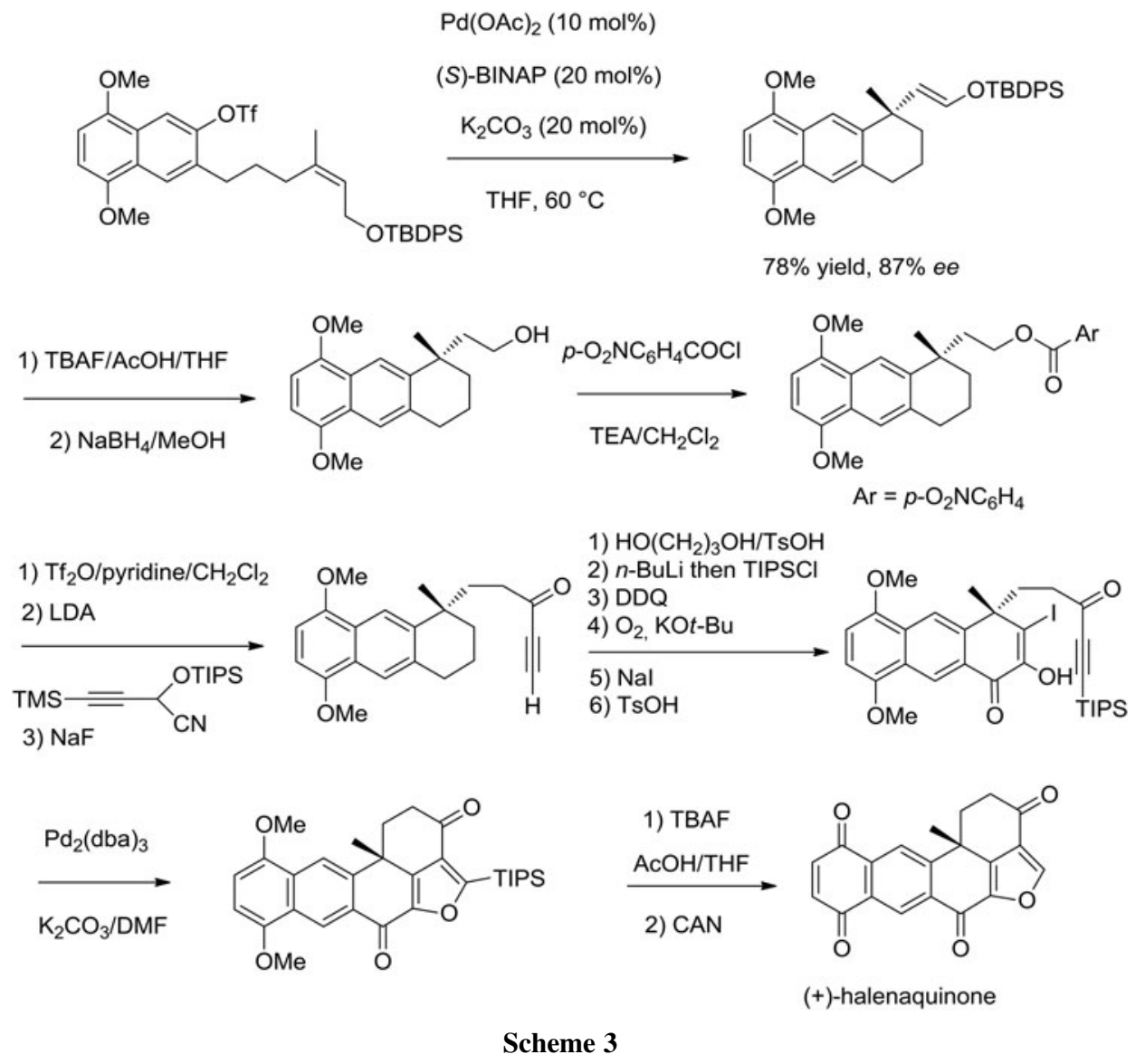

were obtained in moderate to excellent yields (55-94\%) and high enantioselectivities $(85-99 \% e e)$. One of these compounds $\left(\mathrm{R}^{1}=\mathrm{R}^{2}=\mathrm{Me}, \mathrm{R}^{3}=\mathrm{H}, \mathrm{R}^{4}=\mathrm{Ph}\right.$ ) obtained with $71 \%$ yield and $94 \%$ ee was converted into (+)-esermethole through five supplementary steps. The first step dealt with the reduction of this oxindole with $\mathrm{LiAlH}_{4}$, providing the corresponding pyrroloindoline without erosion of the enantiomeric purity. The latter product was successively submitted to reductive cleavage of the $N-N$ bond of the hydrazine by treatment with $\mathrm{SmI}_{2}$, followed by $N$-methylation with formaldehyde and $\mathrm{NaBH}(\mathrm{OAc})_{3}$, which led to the corresponding $N$-methylated product. The latter was further converted into $(+)$-esermethole through successive regioselective bromination with NBS and CuI-catalyzed methoxylation of the resulting bromide.

In 2015, Lete et al. reported a novel access to the tetracyclic core of lycorane alkaloids, such as (+)-lycorine, based on an enantioselective intramolecular domino double Heck reaction of $N$-benzyl-2,3-dialkenylpyrroles. ${ }^{36}$ As shown in Scheme 6, this process was promoted by a chiral palladium catalyst generated in situ from $\mathrm{Pd}(\mathrm{OAc})_{2}$ and $(R)$ BINAP as chiral ligand in the presence of 1,2,2,6,6-pentamethylpiperidine (PMP) as base, providing the corresponding chiral pyrrolophenanthridines in moderate to good yields $(38-68 \%)$ and low to moderate enantioselectivities $(7-72 \%$ ee). 


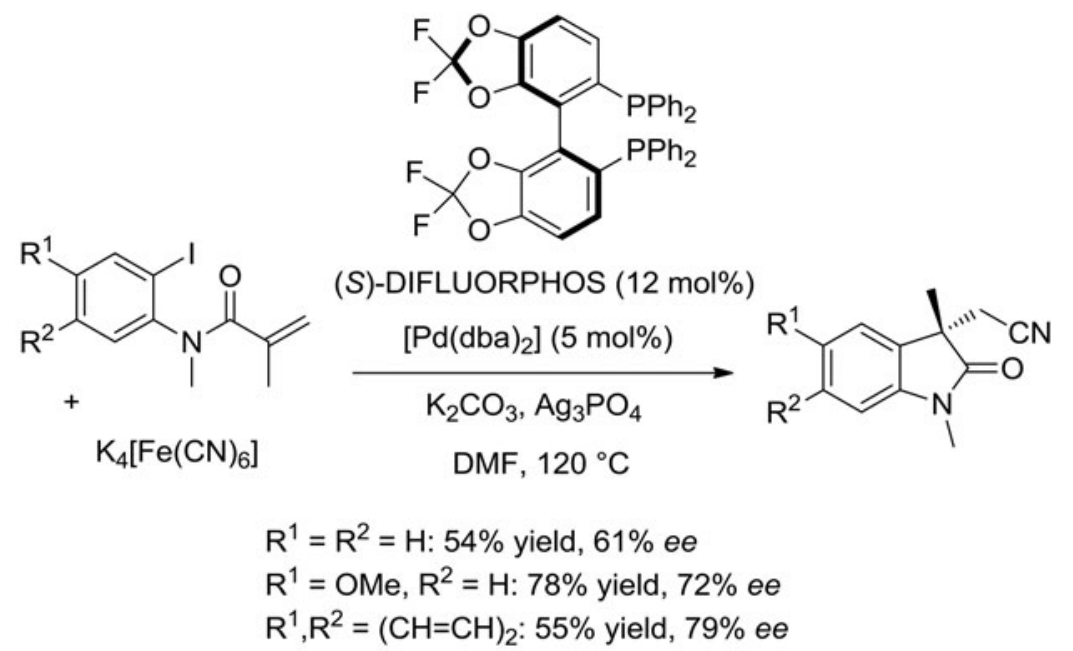<smiles>COc1ccc2c(c1)C(C)(CC#N)C(=O)N2C</smiles><smiles>COc1ccc2c(c1)C1(C)CCNC1N2C</smiles>

$72 \%$ ee<smiles>COc1ccc2c(c1)C1(C)CCN(C)[C@H]1N2C</smiles>

$\mathrm{NaH}$<smiles>CN1CCC2(C)c3cc(O)ccc3N(C)[C@H]12</smiles><smiles>CNC(=O)Oc1ccc2c(c1)[C@@]1(C)CCN(C)[C@H]1N2C</smiles>

(-)-physostigmine

Scheme 4

\section{Wacker-Initiated Domino Reactions as Key Steps}

Another important process based on palladium catalysis is the Wacker reaction. ${ }^{37,38}$ In 2005, Tietze et al. showed that it was possible to combine this process with a Heck reaction in an enantioselective domino Wacker/Heck reaction. ${ }^{39}$ Later in 2006, this novel methodology was applied by these authors as key step in a novel total synthesis of vitamin $\mathrm{E}{ }^{40}$ As depicted in Scheme 7, this key reaction consisted in the enantioselective palladium-catalyzed domino Wacker/Heck reaction of a benzyl-protected phenol with methyl vinyl ketone performed at room temperature in dichloromethane as solvent. It was promoted by a chiral palladium catalyst generated in situ from $\operatorname{Pd}(\mathrm{TFA})_{2}$ and $(S, S)$-Bn-BOXAX as chiral ligand in the presence of $p$-benzoquinone as reoxidant, leading to the corresponding chiral chroman in good yield (84\%) and excellent enantioselectivity (97\% ee), as shown in Scheme 7. 
<smiles>[R]C(=C)C(=O)N([R1])c1cc([R])ccc1O</smiles><smiles>[R]c1nnc([2H])o1</smiles><smiles>O=Pc1ccccc1C1=N[C@@H](CBr)CO1</smiles>

(20 mol\%)

$\mathrm{PdCl}_{2}(\mathrm{MeCN})_{2}(10 \mathrm{~mol} \%)$

TMG (5 equiv)

$\mathrm{MeCN}, 80^{\circ} \mathrm{C}$

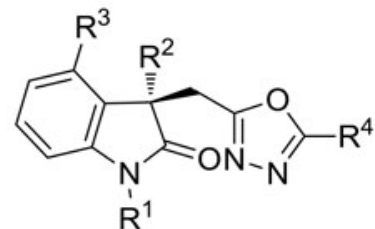

$55-94 \%$ yield, $85-99 \%$ ee

$$
\begin{aligned}
& \mathrm{R}^{1}=\mathrm{Me}, \mathrm{Bn} \\
& \mathrm{R}^{2}=\mathrm{Me}, n-\mathrm{Hex} \\
& \mathrm{R}^{3}=\mathrm{H}, \mathrm{Br}, 6-\mathrm{Cl}, 7-\mathrm{Me} \\
& \mathrm{R}^{4}=\mathrm{Ph}, p-\mathrm{Tol}, p-\mathrm{PhC}_{6} \mathrm{H}_{4}, m-\mathrm{MeOC}_{6} \mathrm{H}_{4}, p-\mathrm{ClC}_{6} \mathrm{H}_{4}, \mathrm{Bn}
\end{aligned}
$$

Synthesis of (+)-esermethole:<smiles>CN1C(=O)[C@](C)(Cc2nnc(-c3ccccc3)o2)c2ccccc21</smiles>

$71 \%$ yield, $94 \%$ ee

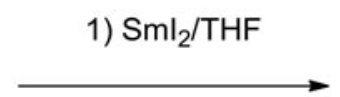

2) $\mathrm{HCHO}, \mathrm{NaBH}(\mathrm{OAc})_{3}$

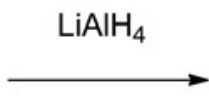<smiles>CN1c2ccccc2[C@@]2(C)CCN(NC(=O)c3ccccc3)[C@H]12</smiles><smiles>CN1CC[C@]2(C)c3ccccc3N(C)[C@H]12</smiles>

1) NBS/DMF

2) $\mathrm{MeOH}, \mathrm{Cul}$<smiles>COc1ccc2c(c1)[C@]1(C)CCN(C)[C@@H]1N2C</smiles>

(+)-esermethole

Scheme 5

This product was further converted into vitamin E through six supplementary steps, beginning with its hydrogenation on $\mathrm{PtO}_{2}$. Then, the boron enolate of the resulting compound was generated by treatment with diisopropylethylamine (DIPEA) as base and $c-\mathrm{Hex}_{2} \mathrm{BCl}$, and then submitted to an aldol reaction with a chiral aldehyde to give an $\alpha, \beta$-unsaturated ketone after treatment with $p$-toluenesulfonic acid. The latter was subsequently submitted to 


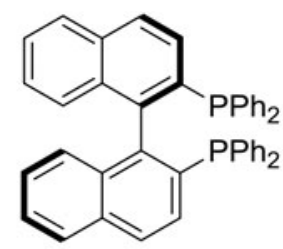<smiles>[X]c1cc(Cn2ccc(C=C)c2C(=C)C)c(I)c([X])c1[X]</smiles>

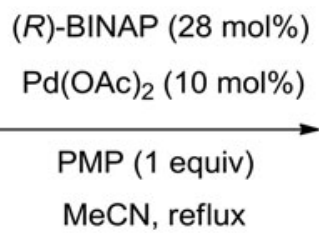<smiles>[Z]c1cc2c(c([X])c1[X])[C@@]1(C)CC=Cc3ccn(c31)C2</smiles>

$38-68 \%$ yield, $7-72 \%$ ee

$\mathrm{X}=\mathrm{H}, \mathrm{OMe}$

$\mathrm{Y}=\mathrm{H}, \mathrm{OMe}, \mathrm{OBn}$

$\mathrm{Z}=\mathrm{OMe}, \mathrm{OBn}$

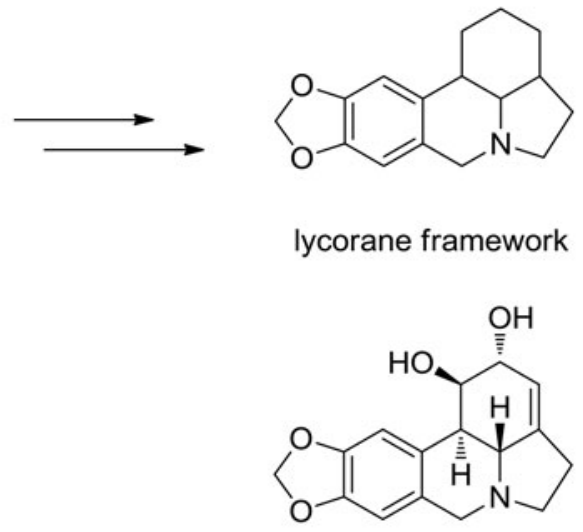

(+)-lycorine

Scheme 6

the addition of methyllithium to its carbonyl moiety to give the corresponding tertiary alcohol, which was converted into the corresponding diene over two steps by means of an elimination catalyzed by $p$-toluenesulfonic acid. Finally, this diene was hydrogenated over $\mathrm{Pd} / \mathrm{C}$ with simultaneous deprotection of the benzylated phenolic hydroxyl group to give vitamin E.

In 2007, Tietze et al. reported another type of enantioselective palladium-catalyzed domino reaction initiated by a Wacker reaction, namely a three-component domino Wacker/carbonylation reaction. ${ }^{41}$ The process occurred between unsaturated phenols, alcohols and carbon dioxide to give the corresponding chiral chromans/benzodioxins with both high yields and enantioselectivities of up to $99 \%$ and $99 \%$ ee, respectively. The reaction was catalyzed by a palladium complex prepared in situ from $\operatorname{Pd}(\mathrm{TFA})_{2}$ and $(S, S)$-Bn-BOXAX as chiral ligand in the presence of $p$-benzoquinone as reoxidant under carbon dioxide atmosphere at ambient pressure. In 2008, the utility of this methodology was demonstrated by the same authors in a total synthesis of the natural 


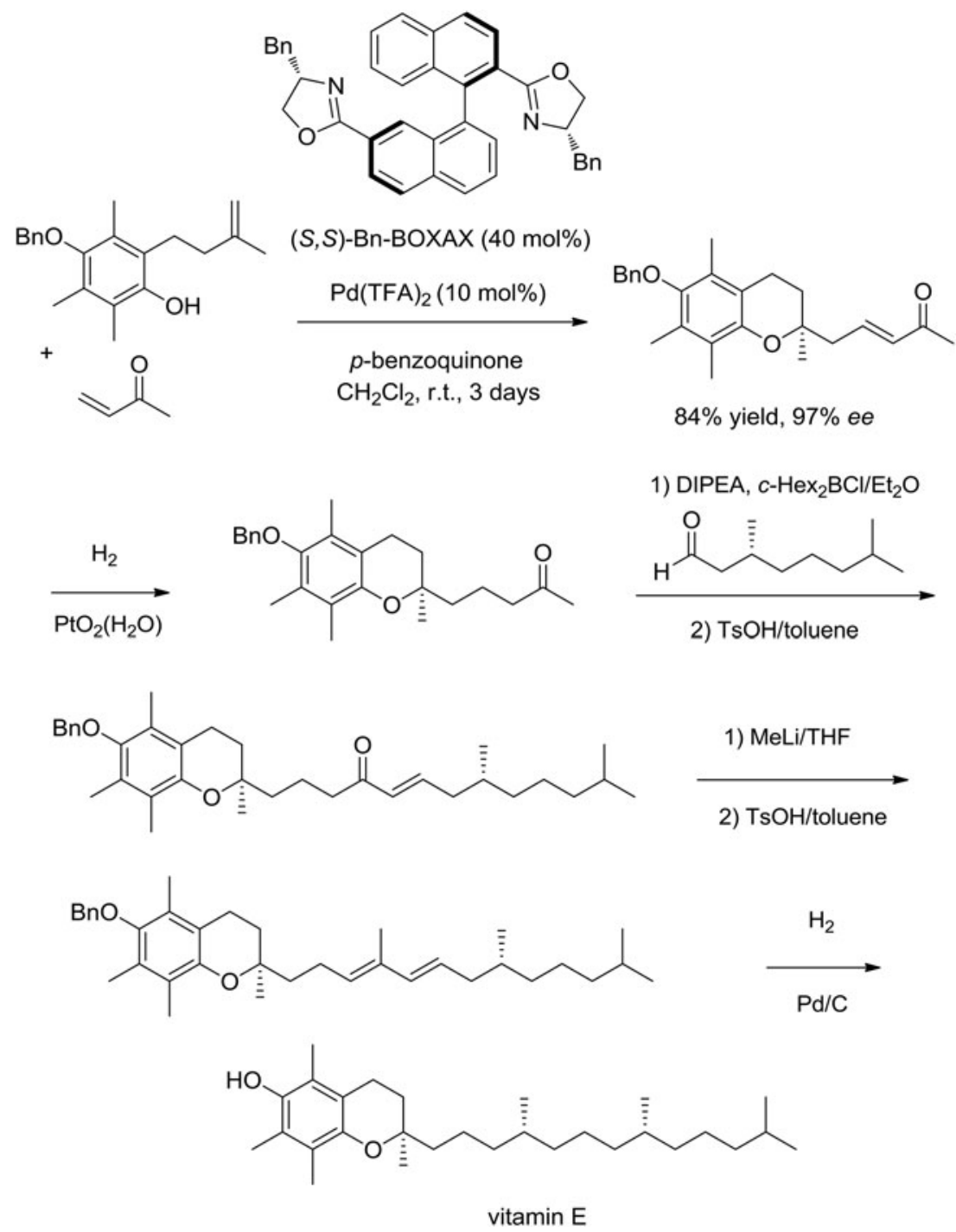

Scheme 7

product 4-dehydroxydiversonol. ${ }^{42}$ As shown in Scheme 8, the key step of this synthesis was the asymmetric domino Wacker/carbonylation reaction of an alkenyl phenol with methanol and carbon dioxide to give at room temperature the corresponding chiral ester in high yield $(80 \%)$ and excellent enantioselectivity $(96 \% e e)$. The latter was further converted into 4-dehydroxydiversonol through eight subsequent steps. The two first steps involved a reduction by treatment with diisobutylaluminum hydride (DIBAL-H) followed by a Wittig - Horner reaction of the thus-formed aldehyde with trimethyl phosphonoacetate, providing the corresponding $\alpha, \beta$-unsaturated ester. The latter was submitted to the hydrogenation of its double bond on $\mathrm{Pd} / \mathrm{C}$ followed by the oxidation of the chroman moiety by treatment with $t \mathrm{BuOOH}$ to give the corresponding chromanone. Then, the intramolecular acylation at the $\alpha$-position of the keto functionality by the ester 

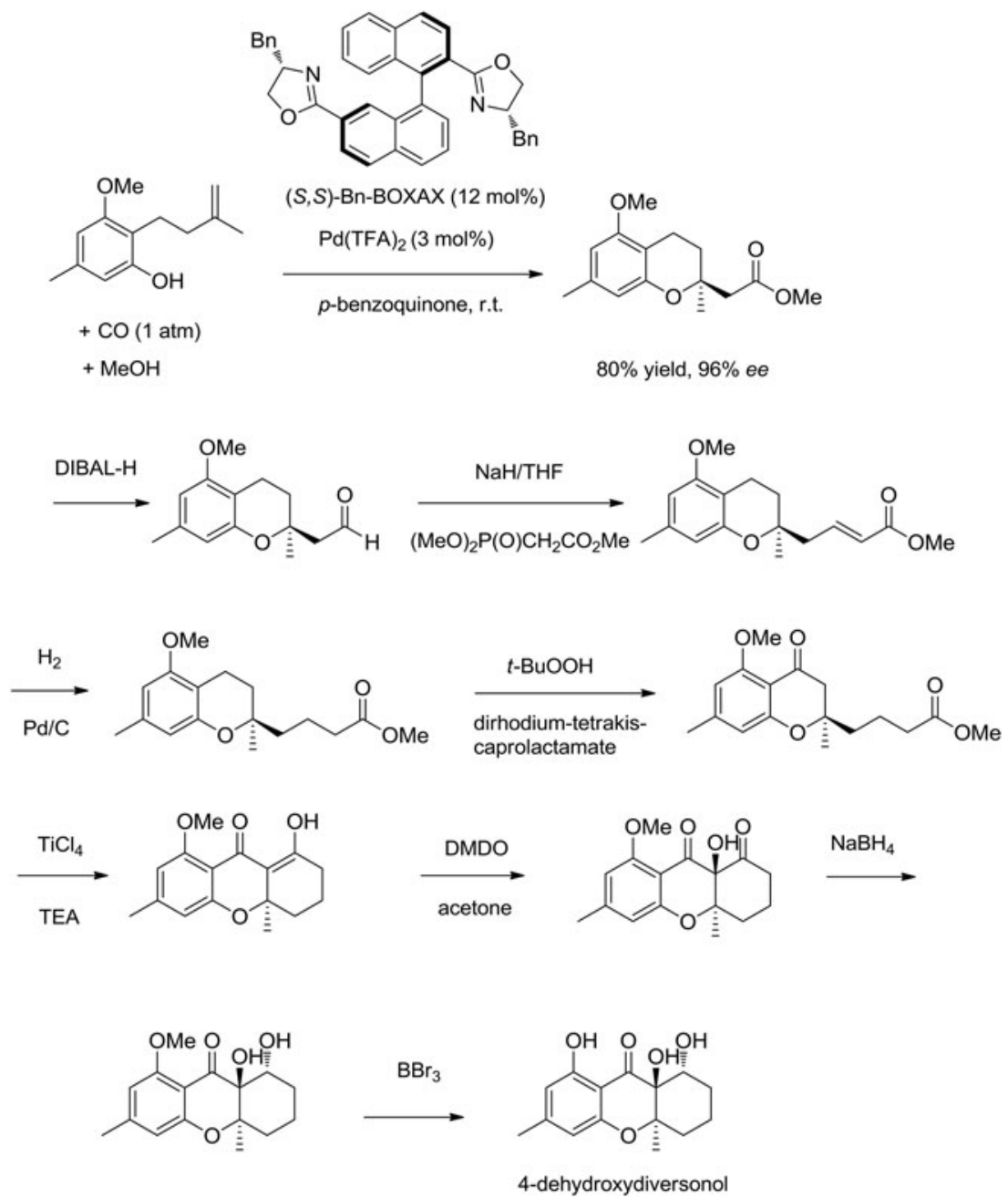

Scheme 8

moiety of this chromanone performed in the presence of $\mathrm{TiCl}_{4}$ and TEA led to the corresponding tetrahydroxanthone. This compound was then oxidized by treatment with dimethyl dioxirane (DMDO) to afford the corresponding trans- $\alpha$-hydroxy diketone as a single diastereomer. Finally, the reduction of the latter with $\mathrm{NaBH}_{4}$ gave exclusively a trans-diol which was further deprotected by treatment with $\mathrm{BBr}_{3}$ to afford the final 4dehydroxydiversonol (Scheme 8).

In 2016, the same methodology was also applied by these authors to develop a formal total synthesis of the natural and biologically active pentacyclic chroman (-)-siccanin. ${ }^{43}$ As shown in Scheme 9, the key step of this synthesis was the treatment of the same alkenyl phenol by a chiral palladium catalyst generated in situ from $\operatorname{Pd}(\mathrm{TFA})_{2}$ and enantiomeric ligand $(R, R)$-Bn-BOXAX under the same reaction conditions, affording the corresponding chiral chroman in good yield $(71 \%)$ and high enantioselectivity (93\% ee). This key intermediate was converted into (-)-siccanin through eight steps, beginning with its reduction with diisobutylaluminum hydride to give the corresponding 


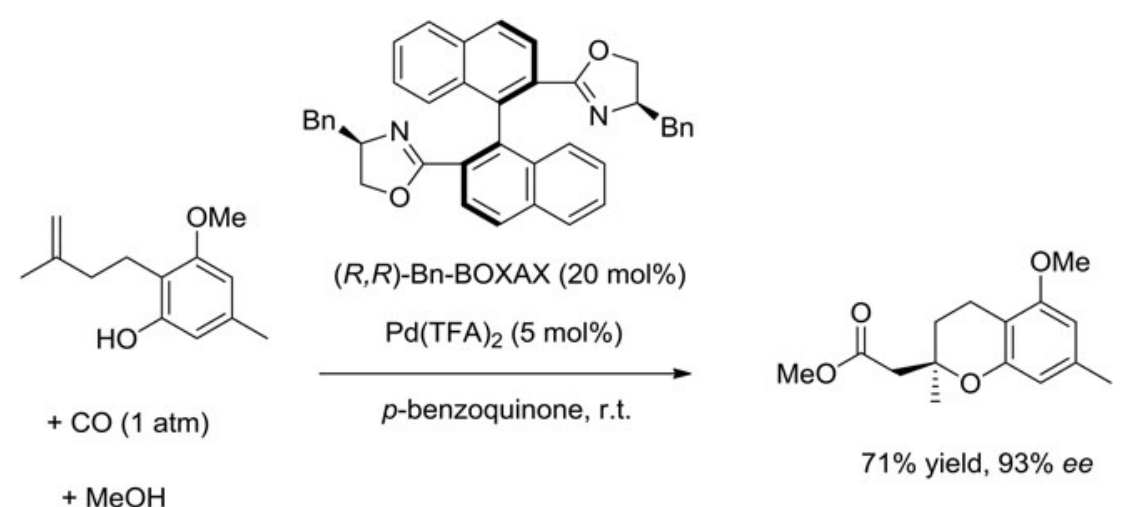

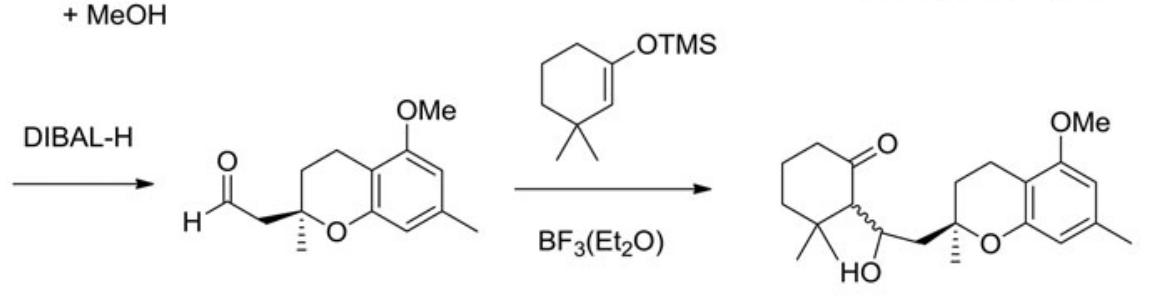<smiles>COc1cc(C)cc2c1CC[C@@H](CCC1C(=O)CCCC1(C)C)O2</smiles><smiles>C=C1CCCC(C)(C)C1CC[C@H]1CCc2c(OC)cc(C)cc2O1</smiles><smiles>C#CC#CC</smiles>

$(-)-$ siccanin

Scheme 9

aldehyde. The latter was submitted to an aldol reaction with a trimethylsilyl enol ether in the presence of $\mathrm{BF}_{3}\left(\mathrm{Et}_{2} \mathrm{O}\right)$ to provide the corresponding aldol product. Then, this compound was treated with Burgess reagent to give the related $\alpha, \beta$-unsaturated ketone as a major diastereomer which was further separated and hydrogenated on $\mathrm{Pd} / \mathrm{C}$ into the corresponding cyclohexanone. The latter was then submitted to a Peterson olefination 


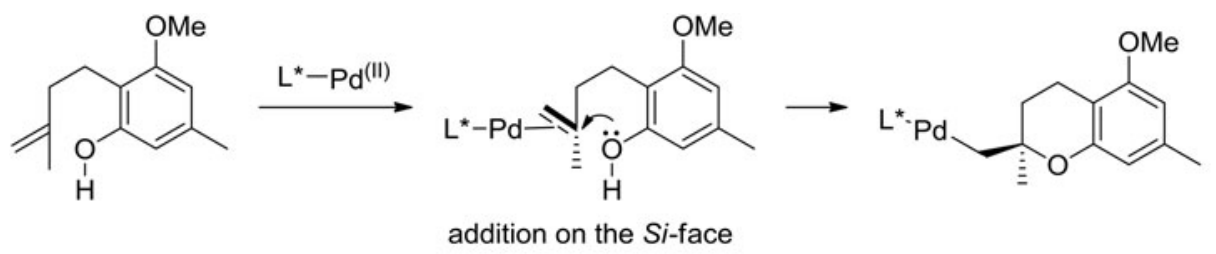<smiles>COC(=O)C[C@]1(C)CCc2c(OC)cc(C)cc2O1</smiles>

to provide the corresponding methylene cyclohexane. A subsequent Sharpless dihydroxylation led to the corresponding diol. This compound constituted a late intermediate in the synthesis of (-)-siccanin earlier reported by Trost et al., in $2003 .{ }^{44}$

A possible mechanism for the key asymmetric domino Wacker/carbonylation reaction of the precedent synthesis is depicted in Scheme 10. It involves the addition of a palladium complex on the $\mathrm{Si}$-face of the external double bond to give an intermediate palladium derivative. The latter was then submitted to a $\mathrm{CO}$ insertion followed by methoxylation to afford the final domino product.

\section{Other Domino Reactions as Key Steps}

In 2009, Trost et al. developed a total synthesis of the naturally occurring anticancer agent (+)-agelastatin A which was based on an enantioselective palladium-catalyzed domino double allylic alkylation reaction. ${ }^{45}$ As illustrated in Scheme 11, the domino reaction of a bis-allylic carbonate with a diamine led to a key intermediate piperazinone in high yield $(82 \%)$ and excellent enantioselectivity $(>97 \% e e)$ when catalyzed by a chiral palladium complex in situ generated from $\left[\mathrm{Pd}_{2}\left(\mathrm{dba}_{3}\right]\left(\mathrm{CHCl}_{3}\right)\right.$ and Trost ligand $(R, R)-\mathrm{L}_{\mathrm{ST}}$ in the presence of acetic acid. This key piperazinone was further converted into (+)-agelastatin A through four further steps, the first one of which was the coppercatalyzed aziridination of the domino product into the corresponding tetracyclic aziridine. The treatment of the latter with $\operatorname{In}(\mathrm{OTf})_{3}$ afforded a tricyclic $\alpha$-amino ketone. Then, the required installation of the D-ring urea of $(+)$-agelastatin A was achieved by treating this $\alpha$-amino ketone with methyl isocyanate in the presence of $\mathrm{Cs}_{2} \mathrm{CO}_{3}$ to give the corresponding tetracyclic compound. Finally, removing the $\mathrm{N}$-Ts and $\mathrm{N}$-OMe groups was achieved through $\mathrm{SmI}_{2}$-mediated radical reduction, leading to (+)-agelastatin $\mathrm{A}$.

\section{Syntheses Based on Copper-Catalyzed Domino Reactions}

\section{Michael-Initiated Domino Reactions as Key Steps}

Related to the growing interest in green chemistry, domino reactions promoted by copper catalysts represent a challenge in organic chemistry. Among them, a number of asymmetric domino reactions are initiated by a Michael addition. For example, an enantioselective three-component copper-catalyzed domino Michael/aldol reaction 


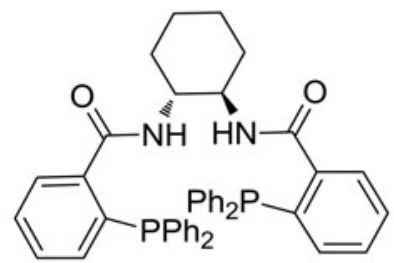

$(R, R)$-L $\mathrm{LT}_{\mathrm{ST}}(15 \mathrm{~mol} \%)$<smiles>CONC(=O)c1ccc(Br)[nH]1</smiles>

$\left[\mathrm{Pd}_{2}(\mathrm{dba})_{3}\right]\left(\mathrm{CHCl}_{3}\right)(5 \mathrm{~mol} \%)$

$\mathrm{AcOH} / \mathrm{CH}_{2} \mathrm{Cl}_{2}$

$0{ }^{\circ} \mathrm{C}$ to r.t.<smiles>CON1C(=O)c2ccc(Br)n2[C@@H]2CC=C[C@H]21</smiles>

$82 \%$ yield, $>97 \%$ ee

Cu catalyst

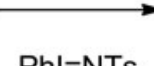

$\mathrm{Phl}=\mathrm{NTs}$

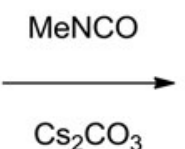<smiles>CON1C(=O)c2ccc(Br)n2[C@H]2C[C@H]3[C@H](S)[C@@H]3[C@@H]21</smiles>

$\ln (\mathrm{OTf})_{3}$

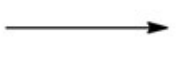<smiles>CON1C(=O)c2ccc(Br)n2[C@@H]2CC(=O)[C@@H](N[PH3+])[C@@H]21</smiles>

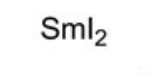<smiles>CN1C(=O)N[C@H]2[C@@H]3NC(=O)c4ccc(Br)n4[C@@H]3C[C@]21O</smiles>

(+)-agelastatin A

Scheme 11

constituted the key step in a total synthesis of (-)-prostaglandin $\mathrm{E}_{1}$ methyl ester reported by Feringa et al., in 2001. ${ }^{46}$ As shown in Scheme 12, this key reaction occurred between a dioxane acetal, a dialkylzinc reagent and an aldehyde in the presence of a copper catalyst in situ generated from $\mathrm{Cu}(\mathrm{OTf})_{2}$ and a chiral phosphoramidite as ligand, giving the corresponding Michael/aldol domino product in $60 \%$ yield as an inseparable 83:17 mixture of diastereomers. The reduction of the ketone moiety in this product proceeded stereoselectively using $\mathrm{Zn}\left(\mathrm{BH}_{4}\right)_{2}$ to give the corresponding diol as a major diastereomer with $94 \%$ ee and $63 \%$ yield. In the next step, the silyl group was removed by treatment with TBAF and then the resulting compound was acetylated with $\mathrm{Ac}_{2} \mathrm{O}$ in pyridine to give the corresponding diacetate. Then, the latter was submitted to a 1,3-allylic transposition in the presence of $\mathrm{Pd}(\mathrm{MeCN})_{2} \mathrm{Cl}_{2}$ to give the corresponding allylic acetate. After deacetylation with $\mathrm{K}_{2} \mathrm{CO}_{3}$ in methanol, a chiral 1,5-diol was 

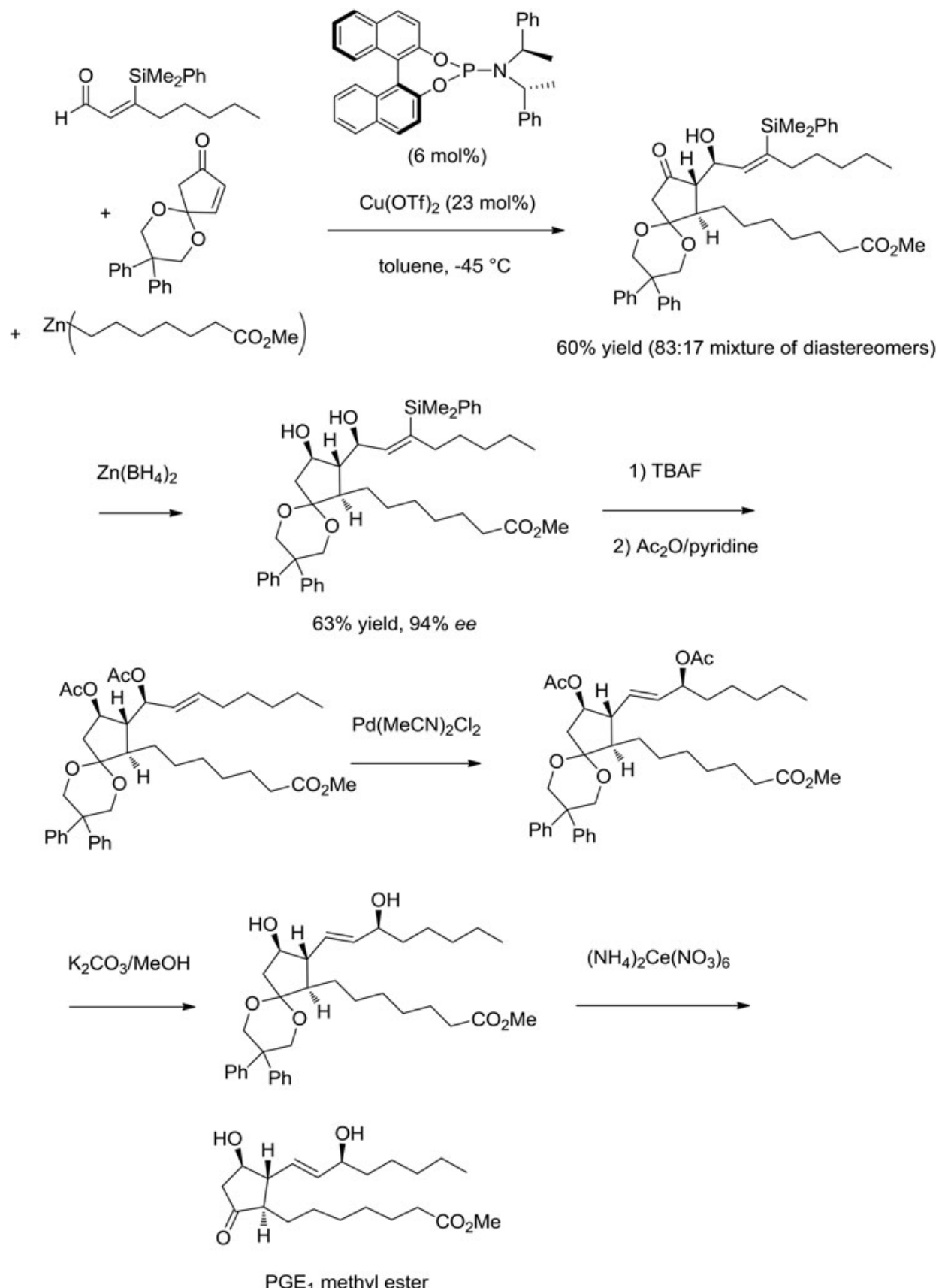

Scheme 12

obtained. The final step of the synthesis dealt with the deprotection of the ketone functionality of this compound by using $\left(\mathrm{NH}_{4}\right)_{2} \mathrm{Ce}\left(\mathrm{NO}_{3}\right)_{6}$, leading to (-)-prostaglandin $\mathrm{E}_{1}$ methyl ester, as detailed in Scheme 12. 


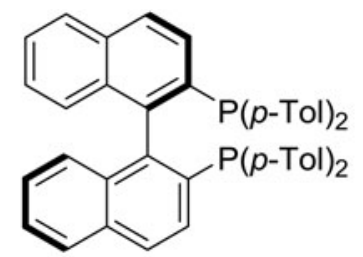

$(R)$-Tol-BINAP $(1.5 \mathrm{~mol} \%)$

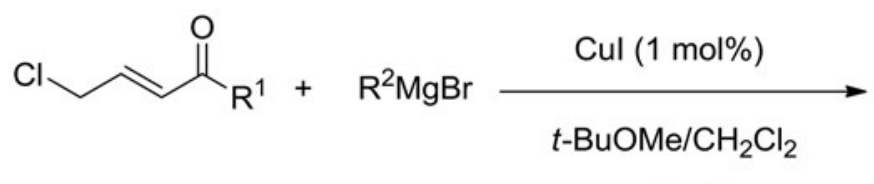

$-78^{\circ} \mathrm{C}$

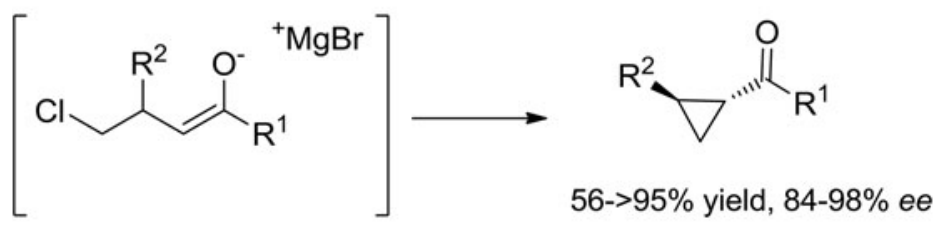

$\mathrm{R}^{1}=\mathrm{SEt}, n-\mathrm{C}_{11} \mathrm{H}_{23}, \mathrm{OMe}$

$\mathrm{R}^{2}=n$ - $\mathrm{Hex}, \mathrm{Me}, \mathrm{Et},\left(\mathrm{CH}_{2}\right)_{3} \mathrm{Ot}-\mathrm{Bu}, \mathrm{BnCH}_{2}$<smiles>O=C(O)[C@@H]1C[C@@H]1O</smiles>

cascarillic acid<smiles>O=C(CC[C@@H]1C[C@H]1O)NCc1ccccc1</smiles>

grenadamide

Scheme 13

In 2010, the same authors reported another enantioselective copper-catalyzed domino reaction initiated by a Michael addition which constituted the key step of formal

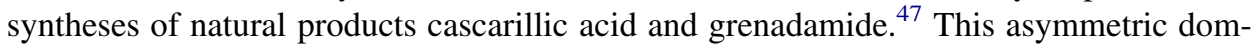
ino Michael/intramolecular alkylation reaction occurred between Grignard reagents and 4-chloro- $\alpha, \beta$-unsaturated esters/thioesters/ketones in the presence of a combination of $\mathrm{CuI}$ and $(R)$-Tol-BINAP as chiral ligand, as shown in Scheme 13. It afforded the corresponding chiral trans-1-alkyl-2-substituted cyclopropane esters/thioesters/ketones in moderate to excellent yields (56->95\%) and high enantioselectivities (84-98\% ee). These various products constituted key intermediates for formal syntheses of cascarillic acid and grenadamide previously reported by Cheeseman and Bull. ${ }^{48}$

In 2012, Riant et al. described the preparation of a key intermediate for a total synthesis of the natural diterpene marrubiin exhibiting antinociceptive and expectorant effects. This was based on an enantioselective copper-catalyzed domino reductive Michael/aldol cyclization reaction. ${ }^{49}$ As shown in Scheme 14, this domino process began with the reductive Michael reaction of a diketoester with phenylsilane performed in the presence of a chiral copper catalyst derived from a Taniaphos ligand, leading to 


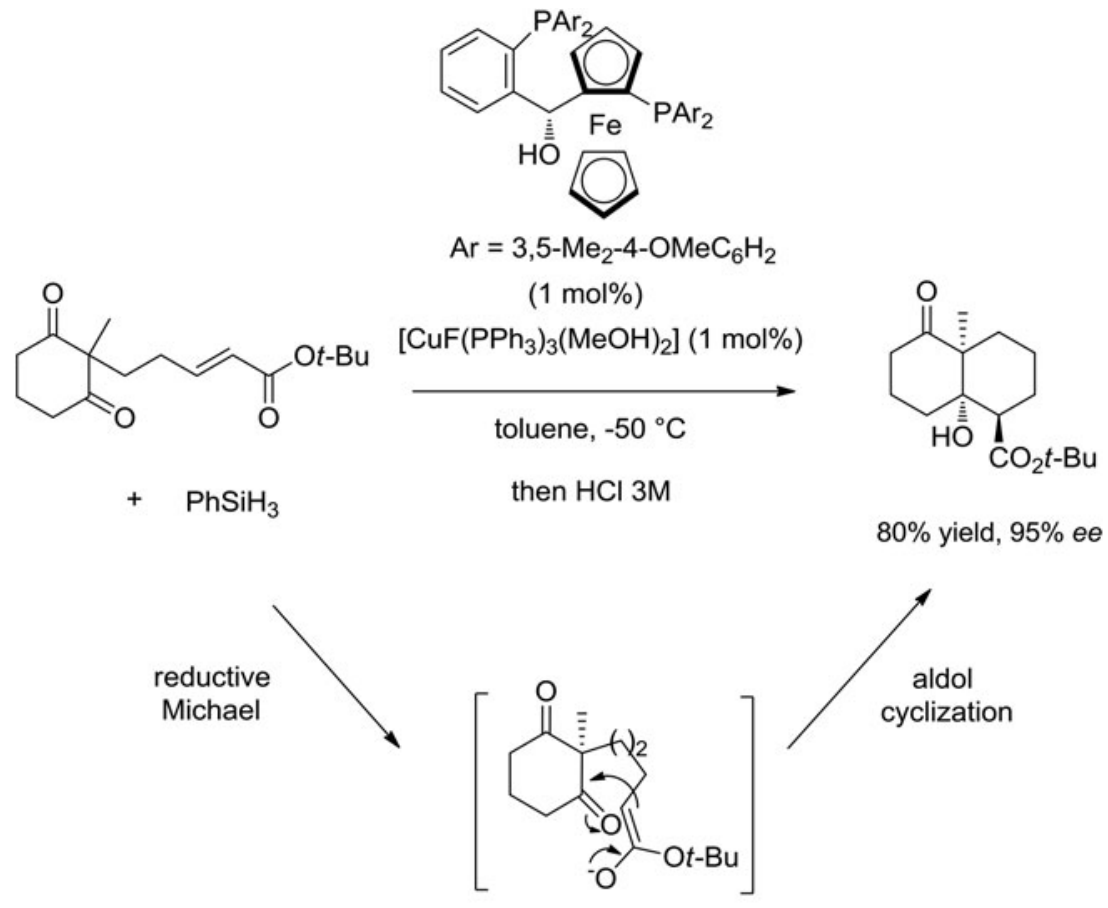

formal synthesis of marrubiin:

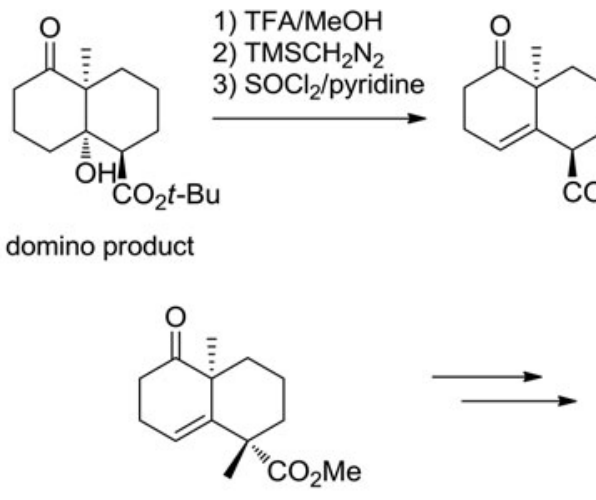

Scheme 14

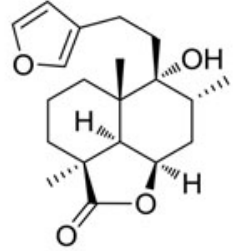

marrubiin

the corresponding bicyclic chiral domino product as a single cis-diastereomer in good yield $(80 \%)$ and excellent enantioselectivity $(95 \% e e)$. This product was further submitted to dehydration by successive treatments with TFA, $\mathrm{TMSCH}_{2} \mathrm{~N}_{2}$ and $\mathrm{SOCl}_{2}$ to give the corresponding non-conjugated cyclohexenone. The latter was then methylated in the presence of LDA and methyl iodide to provide the corresponding bicyclic ester after required protection of the ketone group as dioxolane. This compound constituted a crucial intermediate in the synthesis of marrubiin previously reported. ${ }^{50}$ 


\section{Other Domino Reactions as Key Steps}

In 2011, Hajra and Bar developed an enantioselective copper-catalyzed domino aziridination/Friedel - Crafts cyclization reaction as key step in a total synthesis of the dopamine D1 agonist A-86929. ${ }^{51}$ As depicted in Scheme 15, the reaction of a functionalized styrene with PhINNs was promoted by a copper catalyst in situ generated from $\mathrm{Cu}(\mathrm{OTf})_{2}$ and a chiral bisoxazoline ligand, leading to the corresponding chiral bicyclic domino product in good yield $(82 \%)$, complete trans-diastereoselectivity $(>98 \% d e)$ and excellent enantioselectivity $(95 \% e e)$. This product was converted into A-86929 through four additional steps, beginning with the reaction of its sodium salt generated by treatment with $\mathrm{NaH}$ with $\mathrm{MOMCl}$, providing the corresponding methoxy methyl ether. The Pictet - Spengler-type cyclization of this compound using TMSOTf afforded a tetracyclic product which was subsequently deprotected by treatment with $p$-methoxythiophenol and $\mathrm{K}_{2} \mathrm{CO}_{3}$ to give the corresponding secondary amine. Finally, the demethylation of the latter performed with $\mathrm{BBr}_{3}$ accomplished the synthesis of A-86929.

Earlier in 2006, Knochel et al. had developed a synthesis of the highly toxic alkaloid $(S)-(+)$-coniine, which is known to induce curare-type paralysis. ${ }^{52}$ The key step of this synthesis was an asymmetric copper-catalyzed three-component reaction among butyraldehyde, trimethylsilylacetylene and dibenzylamine catalyzed by a chiral complex derived from $\mathrm{CuBr}$ and (R)-QUINAP as ligand (Scheme 16). This domino process afforded the corresponding chiral propargylamine in both excellent yield $(90 \%)$ and enantioselectivity $(90 \% e e)$. This product was further converted into $(S)-(+)$-coniine through six steps. First, the domino compound was desilylated by treatment with TBAF to give the corresponding alkyne which was subsequently deprotonated with $n$-BuLi and then alkylated with ethylene oxide. After silylation of the resulting alcohol with TIPSCl, the corresponding TIPS ether was obtained. Then, the latter was successively submitted to hydrogenation on $\mathrm{Pd} / \mathrm{C}$, desilylation with $\mathrm{Bu}_{4} \mathrm{NF}$ and intramolecular Mitsunobu reaction to finally afford $(S)-(+)$-coniine.

In 2013, Watanabe and Shibasaki reported a formal total synthesis of antiviral oseltamivir phosphate (Tamiflu) which employed as crucial step another enantioselective copper-catalyzed three-component reaction. ${ }^{53}$ As shown in Scheme 17, the reaction occurred among bis(2-phenylallyl)amine, ethyl propiolate and an aldehyde and was promoted by a chiral copper catalyst in situ generated from $\mathrm{CuBr}$ and a $(R, R)$-O-PINAP ligand. It afforded the corresponding chiral domino product in good yield $(84 \%)$ and moderate enantioselectivity $(76 \% e e$ ). This compound was further converted through a seven-step sequence into Corey's intermediate for the total synthesis of oseltamivir phosphate. The first step of the sequence dealt with the poisoned palladium-catalyzed hydrogenation of the domino product into the corresponding triene followed by a Dieckmann condensation in the presence of LiHMDS to give the corresponding sixmembered compound. The ketone functionality of the latter was further reduced with $\mathrm{NaBH}_{4}$ to give the corresponding alcohol. Then, the two 2-phenylallyl groups of this alcohol were removed by allylic substitution in the presence of $\mathrm{Pd}\left(\mathrm{PPh}_{3}\right)_{4}$ and $N, N$ dimethylbarbituric acid as nucleophile, which was followed by introduction of the Boc group to give the corresponding $N$-Boc-protected amine. Finally, mesylation of the latter followed by subsequent $\beta$-elimination afforded Corey's intermediate for the total synthesis of oseltamivir phosphate. 


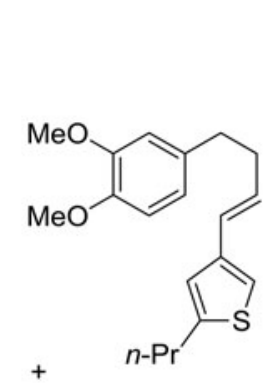

PhINNs
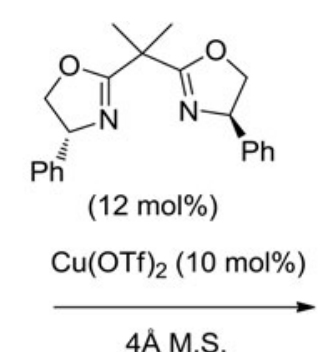

4Å M.S.

$\mathrm{CH}_{2} \mathrm{Cl}_{2},-25^{\circ} \mathrm{C}$

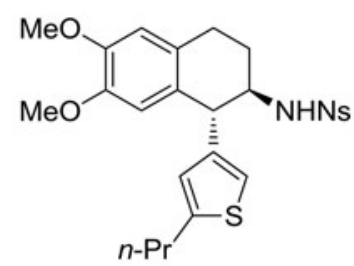

$82 \%$ yield, $>98 \%$ de, $95 \%$ ee

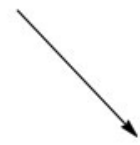<smiles>CCCc1cc([C@](N)(CCc2ccc(OC)c(OC)c2)C2CCCCC2)cs1</smiles>

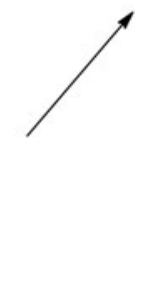

synthesis of A-86929:<smiles>CCCc1cc([C@H]2c3cc(OC)c(OC)cc3CC[C@H]2N)cs1</smiles>

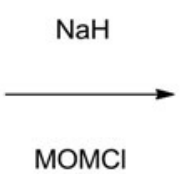

domino product

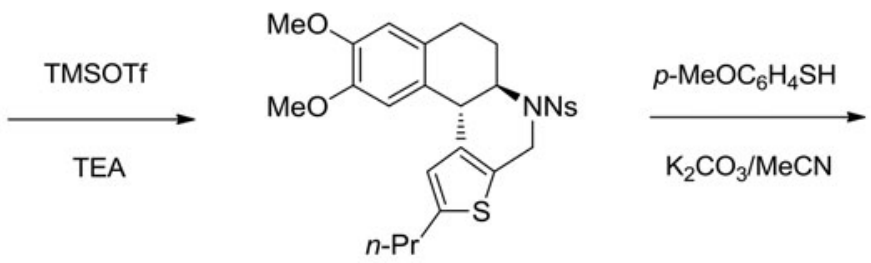<smiles>COc1cc2c(cc1OC)[C@H]1c3cc(C(C)C)sc3CN[C@H]1CC2</smiles><smiles>BrCCCCCCBr</smiles><smiles>CC(C)c1cc2c(s1)CNC1CCc3cc(O)c(O)cc3[C@H]21</smiles>

Scheme 15 


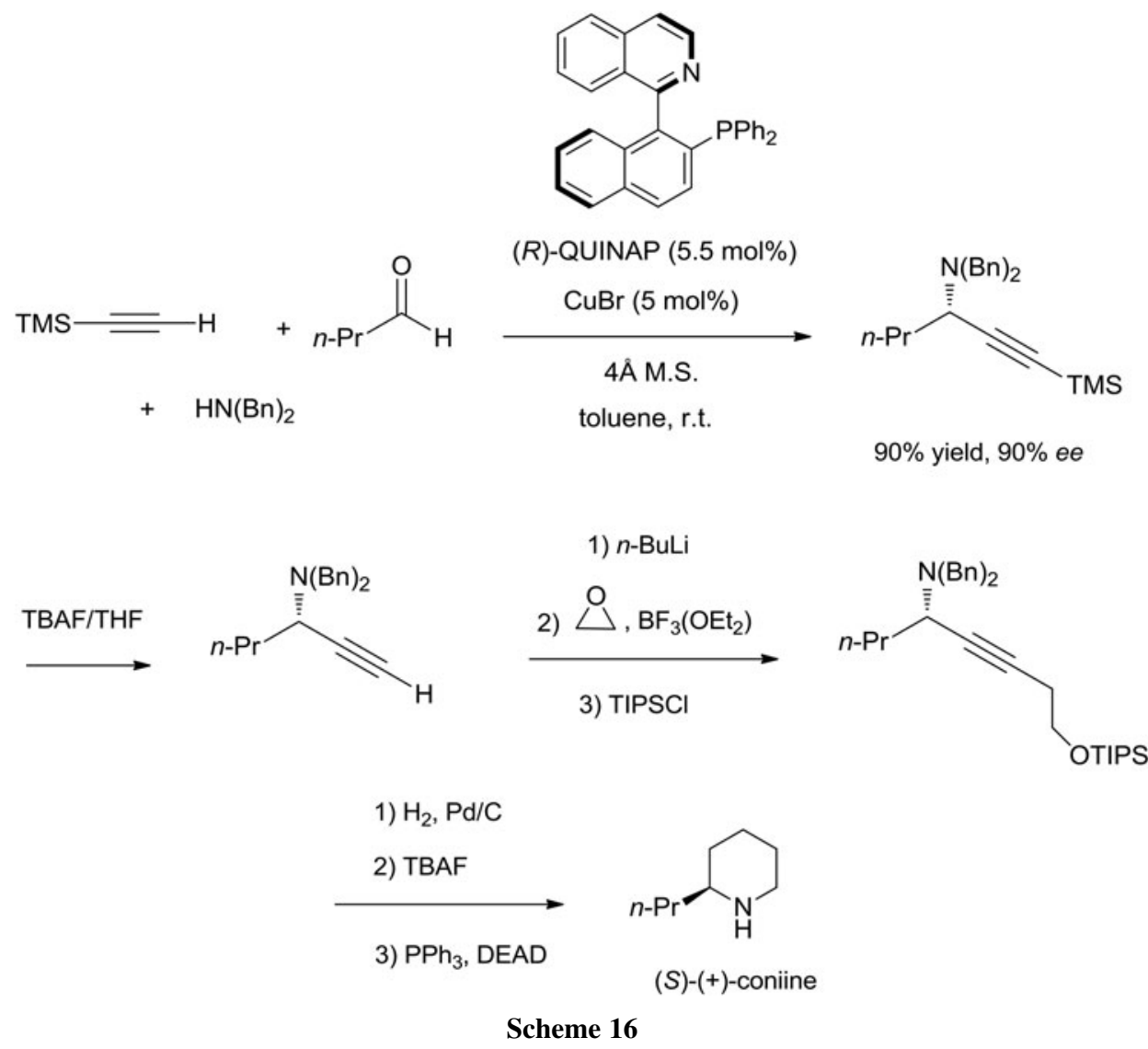

\section{Syntheses Based on Rhodium-Catalyzed Domino Reactions}

Domino carbonyl ylide formation/1,3-dipolar cycloaddition reactions allow a direct access to many complex heterocycles. ${ }^{5-56}$ In 2010, Hashimoto et al. developed an asymmetric version of this methodology as a significant step in a total synthesis of a natural product. ${ }^{57}$ The key intermediate of this synthesis was formed through the enantioselective rhodium-catalyzed domino reaction of the formyl-derived carbonyl ylide generated from a diazo compound with 4-hydroxy-3-methoxyphenylacetylene. When the reaction was catalyzed by $\mathrm{Rh}_{2}(S \text {-TCPTTL })_{4}$, this cycloadduct was obtained in good yield $(73 \%)$ and excellent enantioselectivity (95\% ee), as illustrated in Scheme 18. This product was further converted into the expected natural product having blood circulation properties through eight steps. In the first one, the phenolic ester group of the domino product was protected as tert-butyldiphenylsilyl ether. Then, treatment of this ether by NaHMDS followed by addition of $\mathrm{PhNTf}_{2}$ and subsequent palladium-catalyzed reduction of the resulting enol triflate led to the corresponding 1,4-diene. Then, the reduction of the latter with $\mathrm{LiAlH}_{4}$ and subsequent silylation provided the corresponding diether which was further submitted to allylic oxidation with $\mathrm{SeO}_{2}$ to afford the corresponding allylic alcohol as a single diastereomer. The latter was oxidized with $\mathrm{MnO}_{2}$ to give the corresponding $\alpha, \beta$-unsaturated ketone which was finally converted into the 


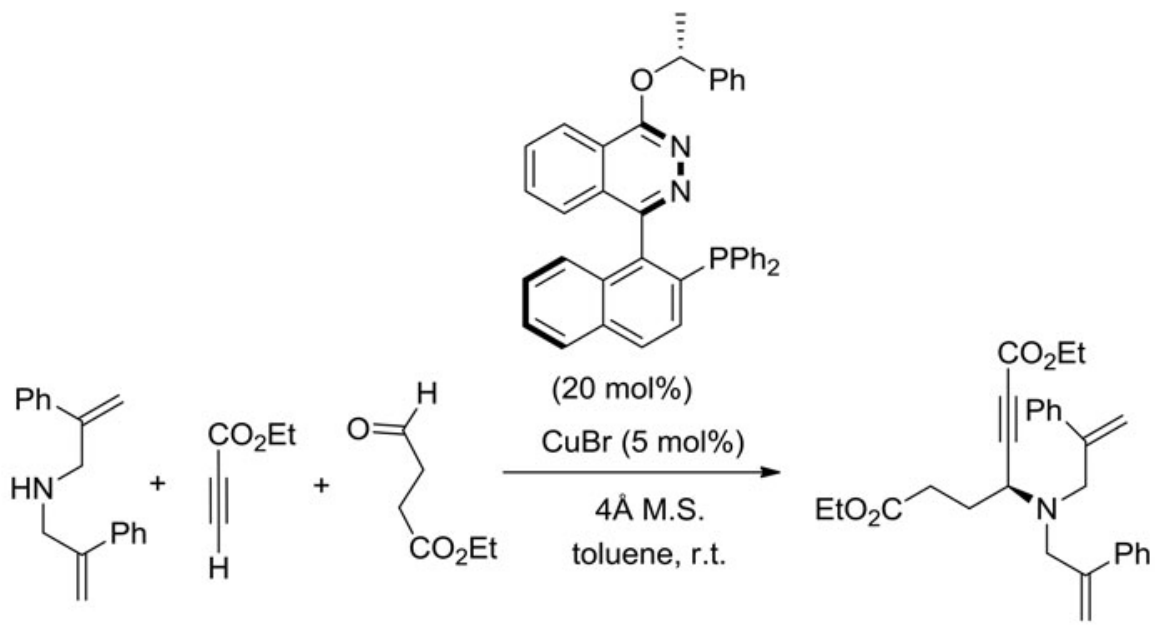

$84 \%$ yield, $76 \%$ ee

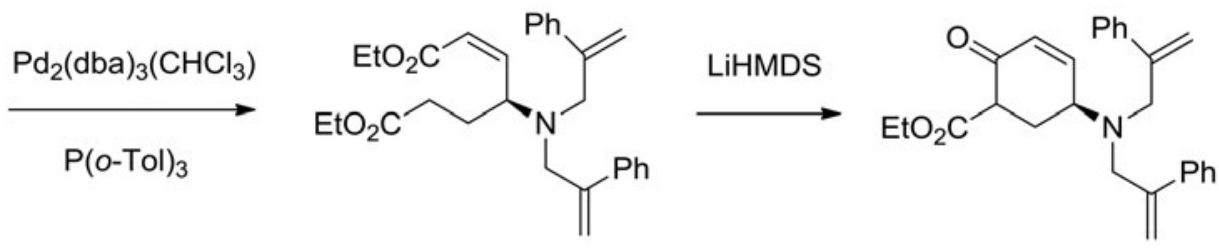

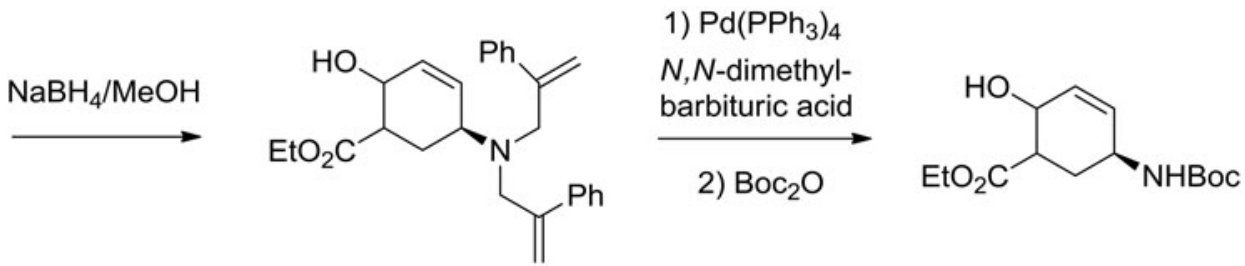

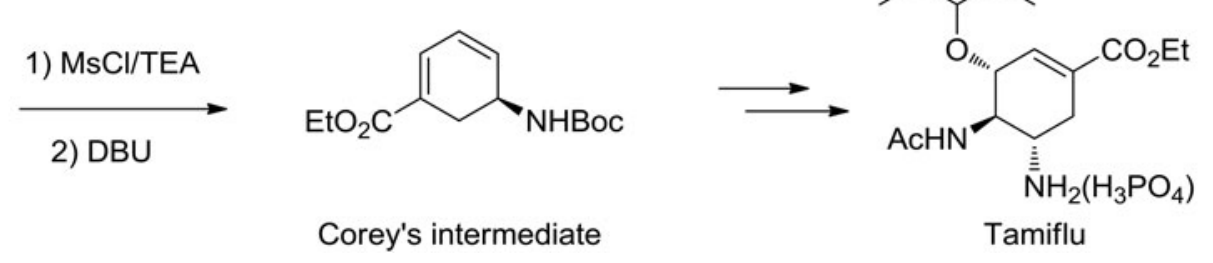

Scheme 17

desired natural product through removing the two TBDPS protecting groups by treatment with TBAF.

The same authors also described the synthesis of another natural and biologically active product, descurainin, on the basis of the same domino reaction albeit catalyzed with the enantiomeric catalyst $\mathrm{Rh}_{2}(R$-TCPTTL $) 4{ }^{58}$ As shown in Scheme 19 , by using this catalyst the corresponding enantiomeric cycloadduct was obtained in good yield $(77 \%)$ and excellent enantioselectivity $\left(\begin{array}{lll}9 \% & e e\end{array}\right)$. A sequence of twelve further 


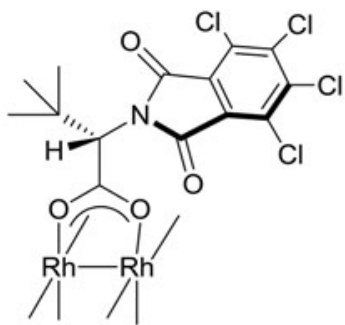

$\underbrace{\mathrm{H}} \stackrel{\mathrm{N}_{2}}{\stackrel{\mathrm{CO}_{2} t-\mathrm{Bu}}{-}+}$

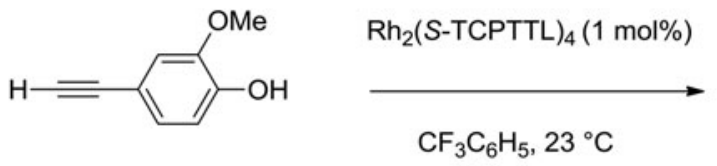

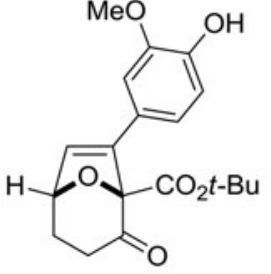

$73 \%$ yield, $95 \%$ ee
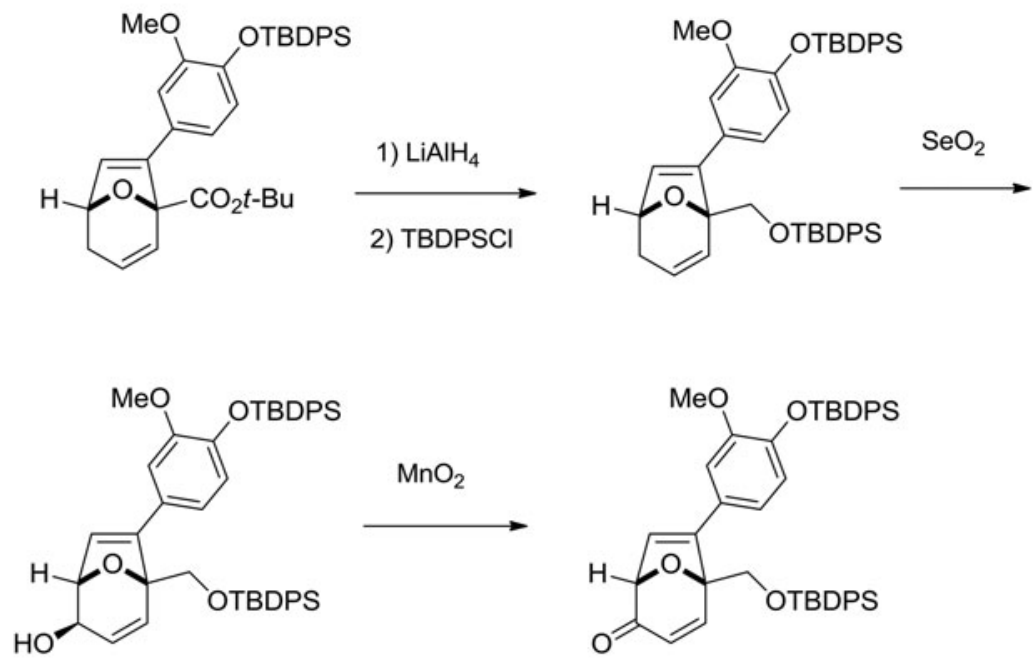

$\mathrm{MnO}_{2}$

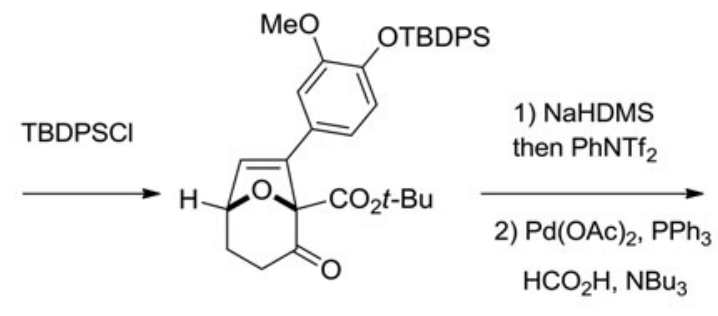

1) NaHDMS then $\mathrm{PhNTf}_{2}$

2) $\mathrm{Pd}(\mathrm{OAc})_{2}, \mathrm{PPh}_{3}$ $\mathrm{HCO}_{2} \mathrm{H}, \mathrm{NBu}_{3}$ 

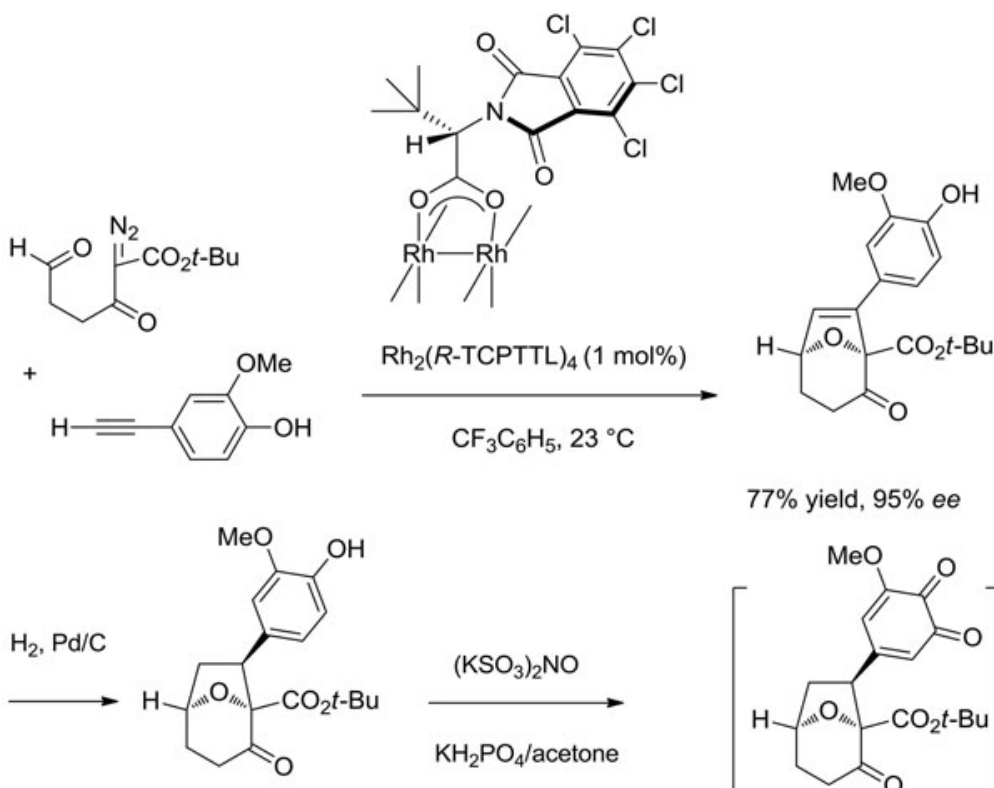

$77 \%$ yield, $95 \%$ ee
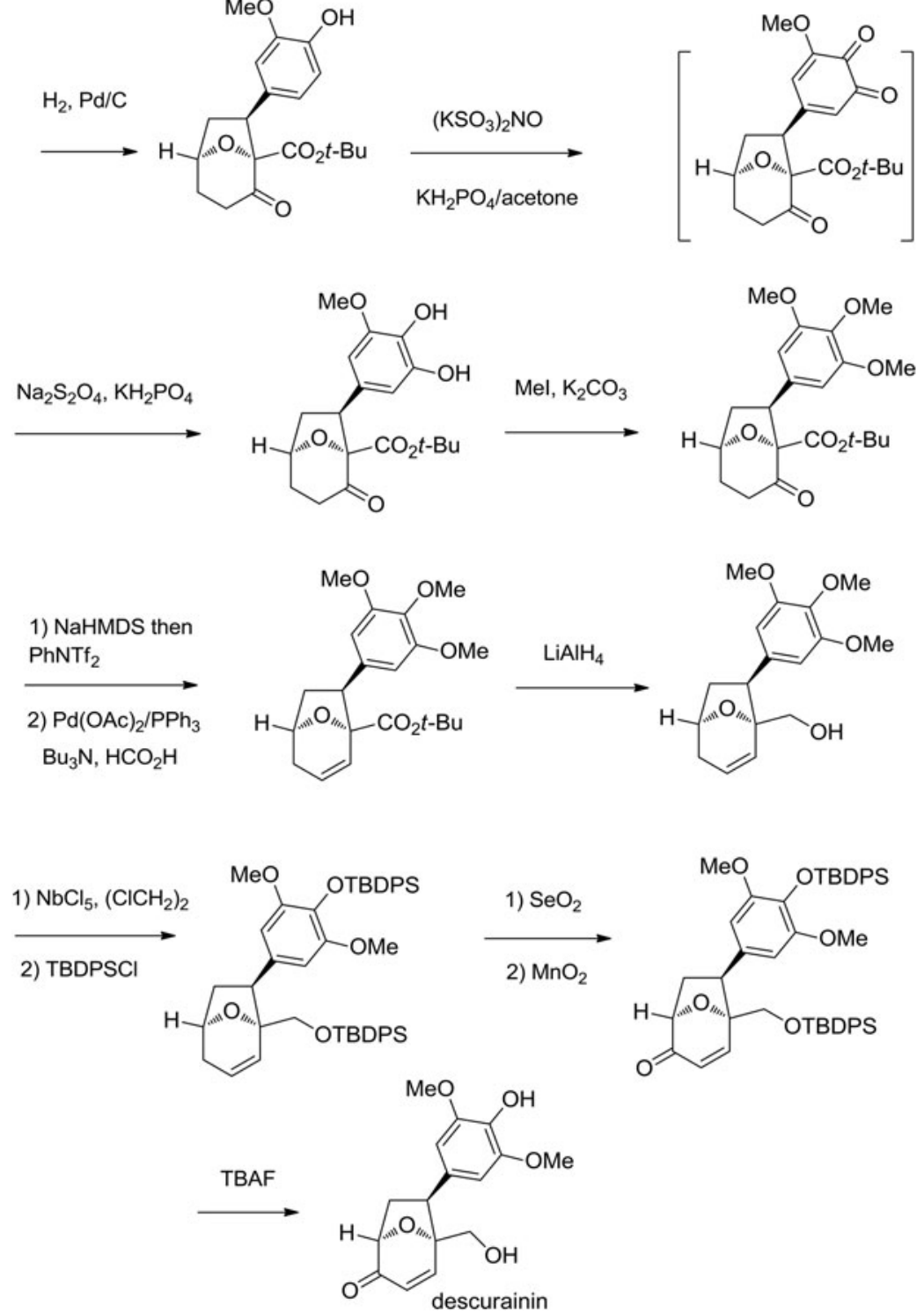

Scheme 19 
supplementary steps allowed expected descurainin to be achieved from this domino product. In the first step, hydrogenation of the latter on $\mathrm{Pd} / \mathrm{C}$ led to the corresponding saturated bicyclic compound as a single diastereomer, which was then treated with $\left(\mathrm{KSO}_{3}\right)_{2} \mathrm{NO}$ in the presence of $\mathrm{KH}_{2} \mathrm{PO}_{4}$ to give the corresponding $o$-quinone. The latter was directly converted into a catechol by treatment with $\mathrm{Na}_{2} \mathrm{~S}_{2} \mathrm{O}_{4}$. Subsequent treatment of this catechol with methyl iodide and $\mathrm{K}_{2} \mathrm{CO}_{3}$ led to the corresponding per-methylated compound. Then, treatment of the latter with NaHMDS followed by addition of $\mathrm{PhNTf}_{2}$ and subsequent palladium-catalyzed reduction of the resulting enol triflate gave the corresponding alkene. The further reduction of the latter with $\mathrm{LiAlH}_{4}$ led to the corresponding alcohol. Subsequent treatment of this alcohol with $\mathrm{NbCl}_{5}$ allowed regioselective demethylation to give the corresponding phenol as a sole product. Then, protection of the two hydroxyl groups of this phenol with TBDPSCl provided the corresponding diether which was further submitted to an allylic oxidation with $\mathrm{SeO}_{2}$ followed by an oxidation with $\mathrm{MnO}_{2}$ to give the corresponding $\alpha, \beta$-unsaturated ketone. Finally, the removal of the two TBDPS protecting groups of this enone with TBAF completed the total synthesis of descurainin (Scheme 19).

\section{Syntheses Based on Aluminum-Catalyzed Domino Reactions}

In 1996, Shibasaki et al. reported the first catalytic asymmetric domino Michael/aldol reaction. ${ }^{59}$ Promoted by a heterobimetallic chiral complex, such as AlLibis $[(R)$ binaphthoxide], this three-component reaction between cyclopentenones, aldehydes and methyl-substituted dibenzyl malonates led to the corresponding multifunctionalized chiral cyclopentanones with enantioselectivities of up to $91 \%$ ee. In 1998, this methodology was applied by the same authors to develop a total synthesis of 11-deoxy$\mathrm{PGF}_{1 \alpha}{ }^{60}$ As shown in Scheme 20, the three-component domino Michael/aldol reaction of cyclopentenone, an aldehyde and dibenzyl methylmalonate performed in the presence of enantiomeric AlLibis[ $(S)$-binaphthoxide] provided the corresponding chiral product in $84 \%$ yield and up to $88 \%$ de. This domino product was further converted through fourteen steps into 11-deoxy-PGF $1 \alpha$. The sequence began with the conversion of the domino product into the corresponding $\alpha, \beta$-unsaturated ketone through successive mesylation and elimination. Then, hydrosilylation of this ketone catalyzed by chlorotris(triphenylphosphine)rhodium gave the corresponding trans-ketone which was subsequently reduced with L-Selectride into the corresponding alcohol as a single product. Then, this alcohol was protected with tert-butyldimethylsilyl trifluoromethanesulfonate to give the corresponding TBS ether. The latter was further transformed into the corresponding methyl ketone through successive treatments with hydrogen on $\mathrm{Pd} / \mathrm{C}$, $\mathrm{Pb}(\mathrm{OAc})_{4}$ and $\mathrm{K}_{2} \mathrm{CO}_{3}$. Then, the aldol reaction of this methyl ketone with hexanal followed by elimination provided the corresponding $\alpha, \beta$-unsaturated ketone. The subsequent treatment of this ketone with La-(S)-3-(hydroxymethyl)binaphthol complex led to the corresponding epoxide which was further subjected to Wharton reaction conditions to give the corresponding allylic alcohol. Finally, the deprotection of this alcohol by treatment with $\mathrm{HF}$ led to 11-deoxy-PGF $1 \alpha$.

Another asymmetric aluminum-catalyzed three-component reaction was developed by Shibasaki et al., involving a pyridine derivative, TMSCN and a carbonyl chloride as substrates. ${ }^{61}$ Promoted by a chiral aluminum catalyst in situ generated from $\mathrm{Et}_{2} \mathrm{AlCl}$ and a BINOL-derived sulfoxide chiral ligand, it afforded the corresponding chiral cyanide in quantitative yield $(98 \%)$ and high enantioselectivity $(91 \% e e)$, as shown in 


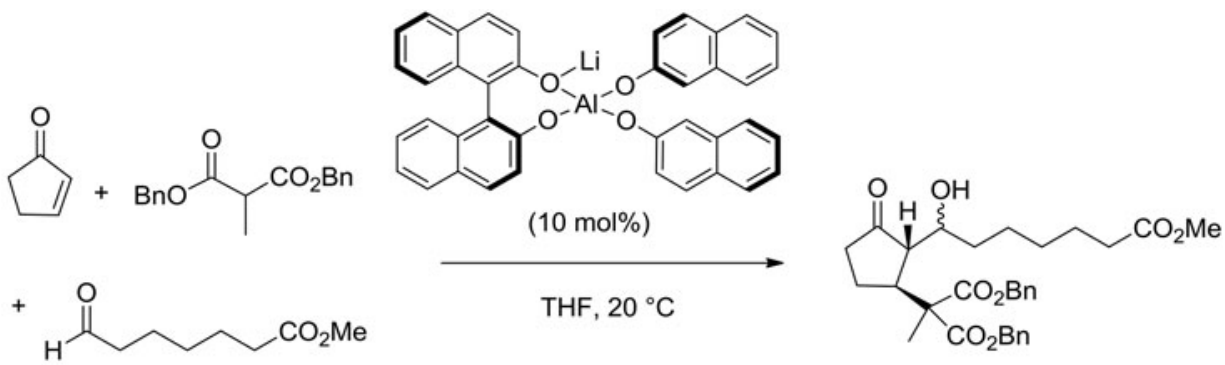

$84 \%$ yield, up to $88 \%$ de
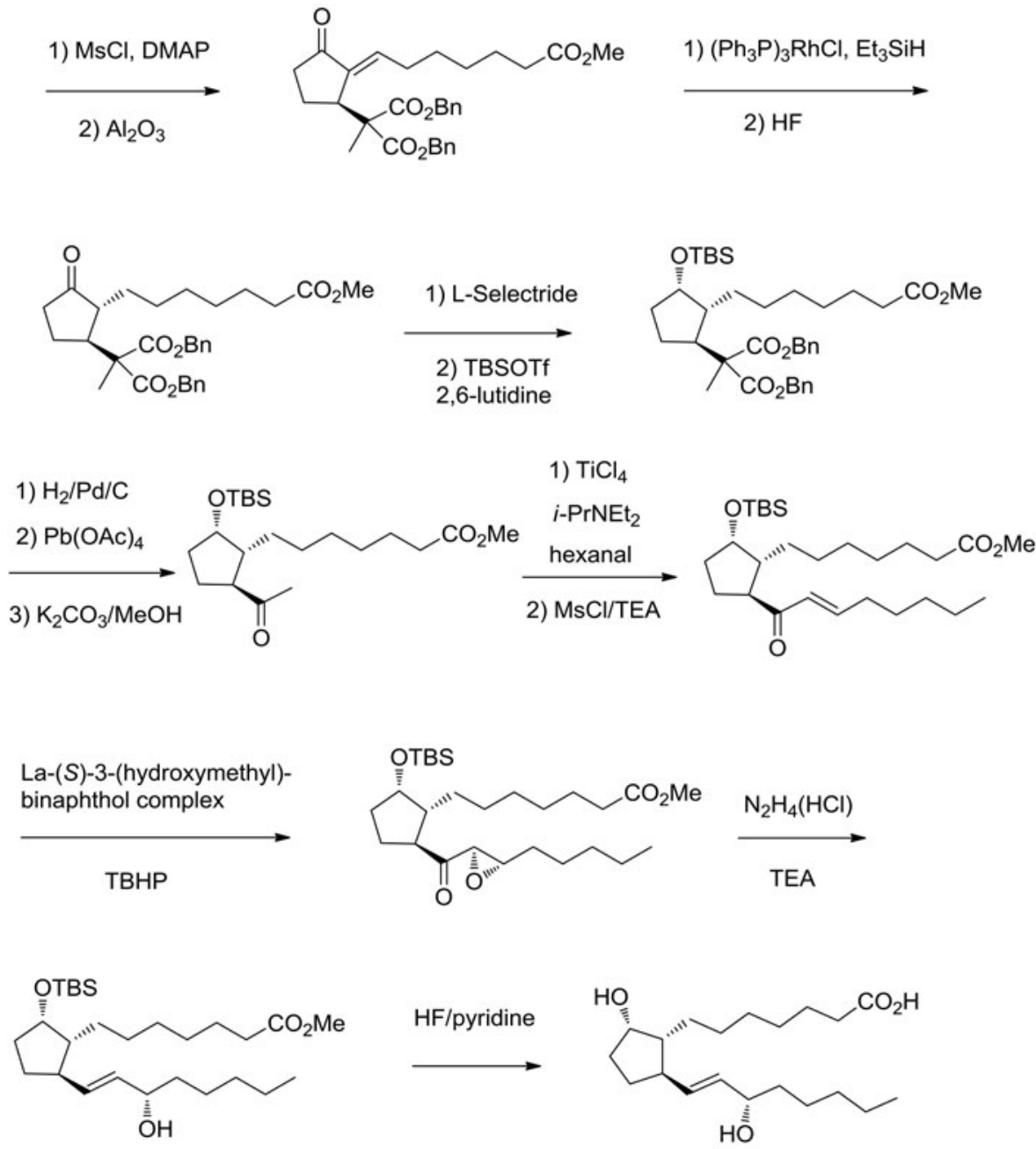

11-deoxy-PGF1 $\alpha$

Scheme 20 


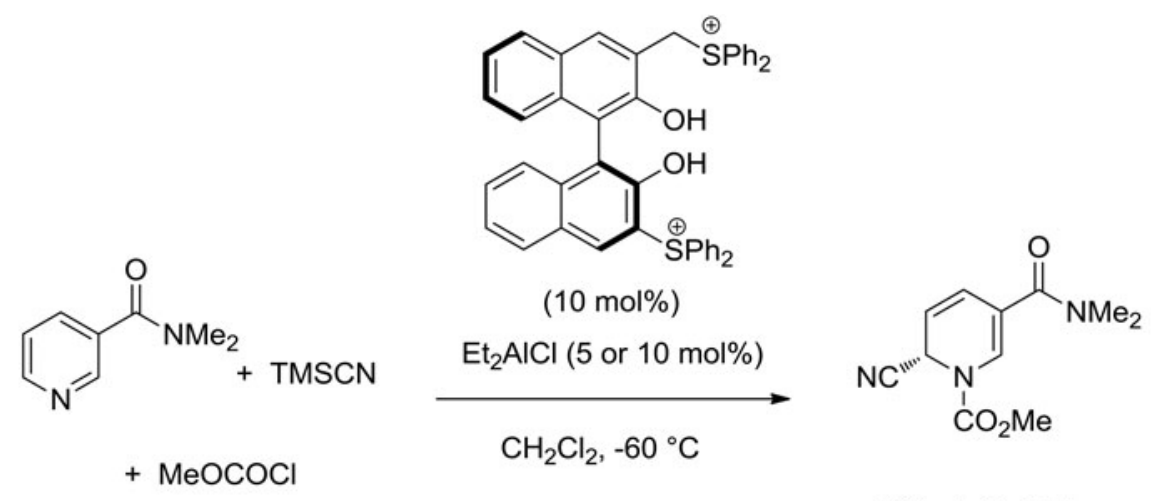

$98 \%$ yield, $91 \%$ ee

1) $\mathrm{H}_{2}, \mathrm{Pd} / \mathrm{C}$
2) $\mathrm{H}_{2}, \mathrm{Pd} / \mathrm{C}, \mathrm{HCl}$
$\longrightarrow$

3) $\mathrm{TsCl} / \mathrm{TEA}$

4) $\mathrm{NaOH}$<smiles>CN(C)C(=O)C1=CN[C@H](CN)CC1</smiles>

1) $\mathrm{NaBH}_{3} \mathrm{CN}$<smiles>CNC(=O)[C@@H]1CC[C@@H]2CN([As])CCN2C1</smiles>

1) $\mathrm{BuLi}, \mathrm{BH}_{3}\left(\mathrm{NH}_{3}\right)$

2) $\mathrm{Na}$, naphthalene

3) $\mathrm{Boc}_{2} \mathrm{O} / \mathrm{DMAP}$

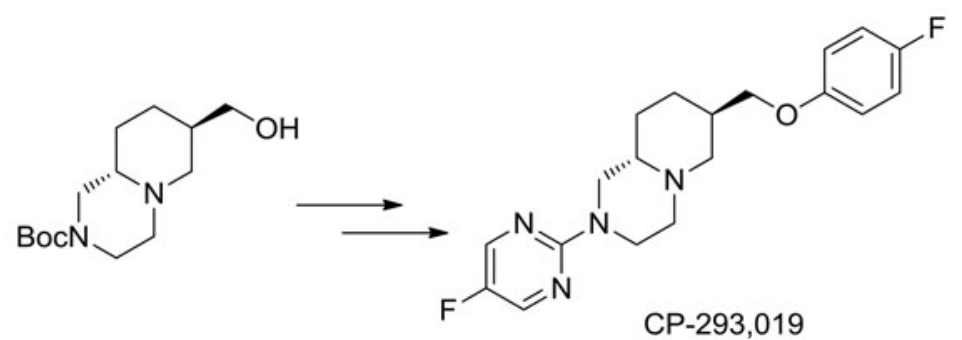

Scheme 21

Scheme 21. The synthetic utility of this methodology was demonstrated by its application to the formal synthesis of the dopamine $\mathrm{D}_{4}$ receptor-selective antagonist $\mathrm{CP}$ 293,019. ${ }^{62}$ Indeed, the domino product was converted through nine steps into an important primary alcohol intermediate in the synthesis of CP-293,019. The synthetic route began with a two-step hydrogenation of the domino product followed by a protection/deprotection sequence, leading to the corresponding tetrahydropyridine. Reduction of the latter with $\mathrm{NaBH}_{3} \mathrm{CN}$ via an iminium cation proceeded in a 4:1 ratio, and the isolated major diastereomer was annulated to give a bicyclic diamine. Then, the known key primary alcohol intermediate ${ }^{63}$ was achieved from this bicyclic diamine in three supplementary steps.

\section{Syntheses Based on Domino Reactions Catalyzed by Other Metals}

In 1999, Ihara and Nemoto reported a total synthesis of the natural product (+)-equilenin based on an asymmetric manganese-catalyzed domino epoxidation/ring-expansion 


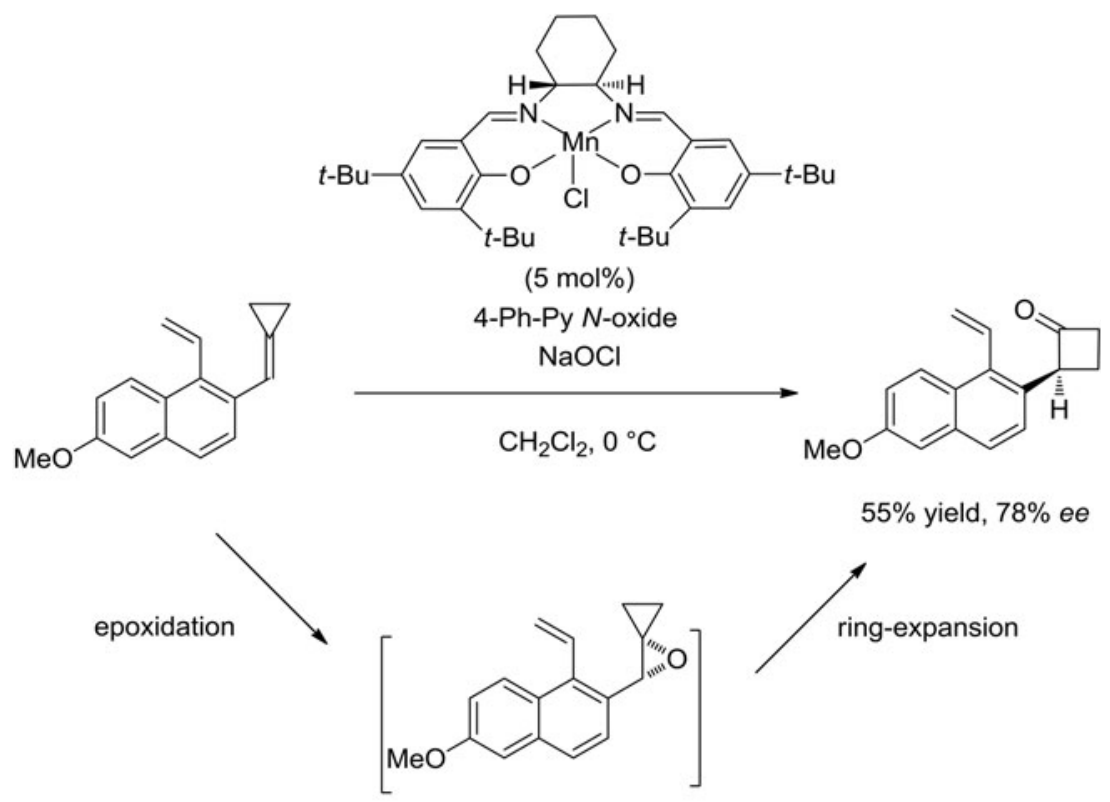

synthesis of (+)-equilenin:
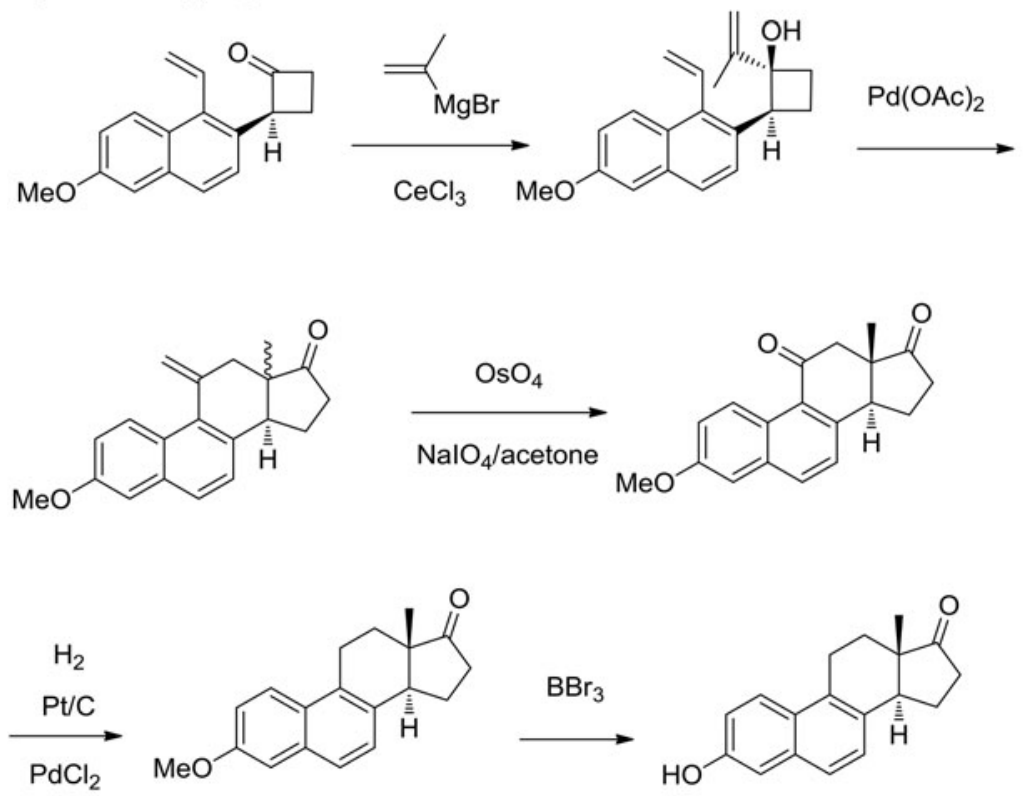

(+)-equilenin

Scheme 22

reaction of a cyclopropylidene. ${ }^{64,65}$ This domino process was catalyzed by a chiral preformed salen manganese complex in the presence of sodium hypochlorite as oxidant, leading through successive epoxidation and ring-expansion to the corresponding chiral cyclobutanone in moderate yield $(55 \%)$ and good enantioselectivity $(78 \% e e)$, as 


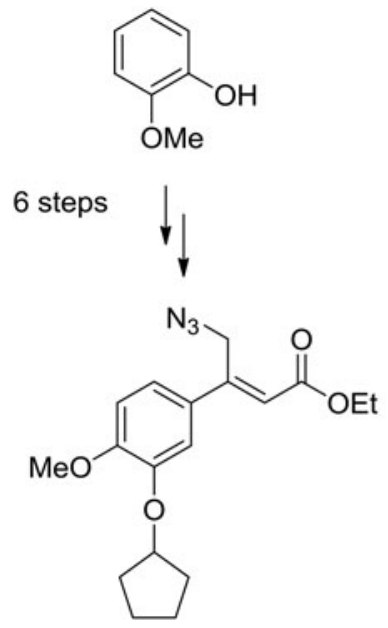

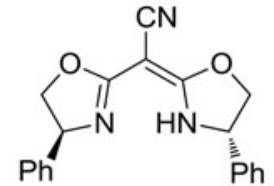

(1.1 mol\%)

$\mathrm{CoCl}_{2}(1 \mathrm{~mol} \%)$

$\mathrm{NaBH}_{4}, 25^{\circ} \mathrm{C}$,

DME:EtOH (1:1)<smiles>COc1ccc([C@H]2CNC(=O)C2)cc1OC1CCCC1</smiles>

(R)-rolipram

$92 \%$ yield, $92 \%$ ee<smiles>O=C1C[C@@H]([AlH2])CN1</smiles>

$82 \%$ yield, $89 \%$ ee

$6 \mathrm{M} \mathrm{HCl}$<smiles>NCC(CC(=O)O)c1ccc(Cl)cc1</smiles>

$(R)$-baclofen

Scheme 23

illustrated in Scheme 22. The latter was converted into the steroid (+)-equilenin through five supplementary steps. This sequence began with the stereoselective conversion of the domino product into the corresponding isopropenylcyclobutanol by Grignard reaction with isopropenylmagnesium bromide in the presence of cerium trichloride. Then, a palladium-mediated cascade ring expansion/insertion reaction occurred to give the corresponding 11-methylene steroid as a diastereomeric mixture which was subsequently treated with osmium tetroxide and sodium periodate to give the corresponding diketone. The latter was further submitted to hydrogenolysis on $\mathrm{Pt} / \mathrm{C}$ in the presence of $\mathrm{PdCl}_{2}$ to afford equilenin methyl ether. A subsequent deprotection performed in the presence of $\mathrm{BBr}_{3}$ led finally to (+)-equilenin.

With the aim of synthesizing precursors to GABA analogues, Sudalai and Paraskar developed in 2006 a novel enantioselective cobalt-catalyzed domino reductive cyclization reaction of substituted $\gamma$-azido- $\alpha, \beta$-unsaturated esters to afford the corresponding $\gamma$-lactams with enantioselectivities of up to $98 \% e e .^{66}$ The process was promoted by a cobalt catalyst in situ generated from $\mathrm{CoCl}_{2}$ and a chiral oxazoline ligand in the 

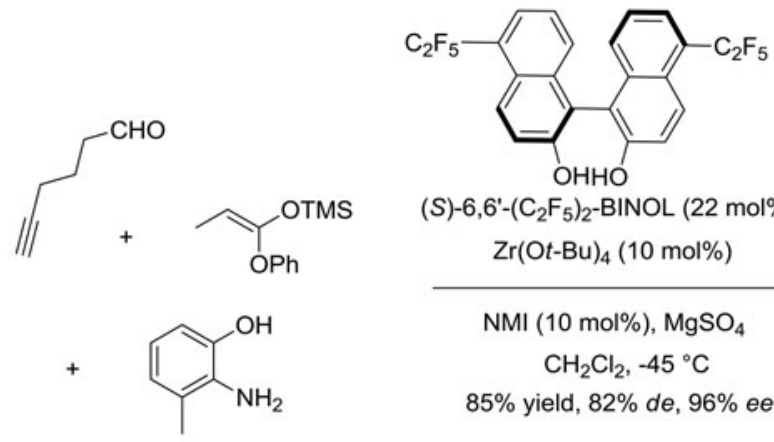

(S)-6,6'- $\left(\mathrm{C}_{2} \mathrm{~F}_{5}\right)_{2}$-BINOL (22 mol\%)

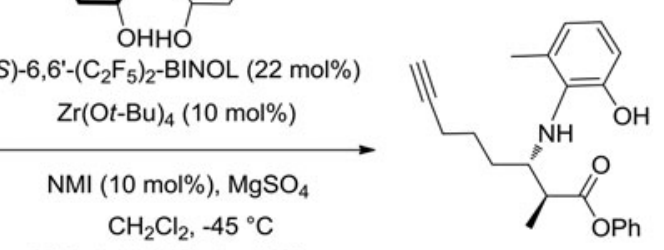

$85 \%$ yield, $82 \%$ de, $96 \%$ ee
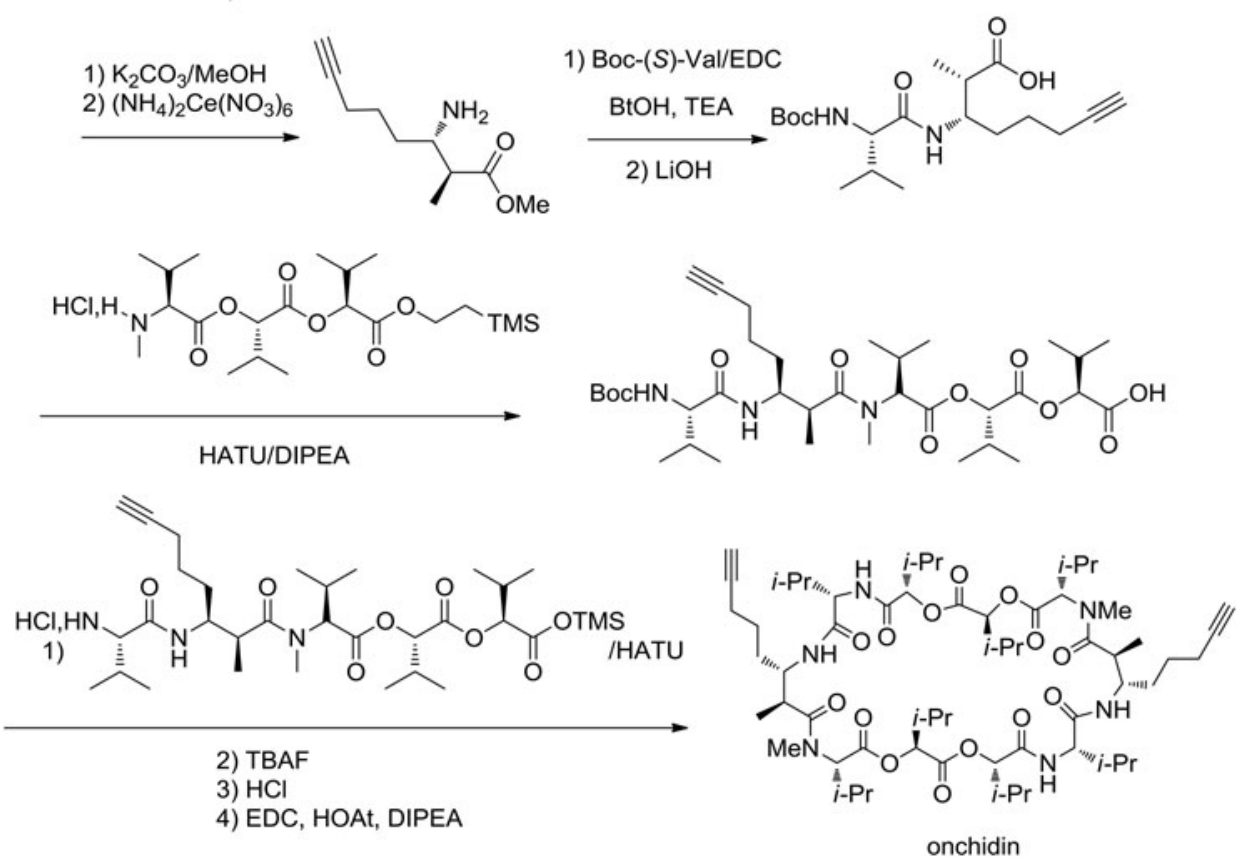

Scheme 24

presence of $\mathrm{NaBH}_{4}$ as reducing agent. This methodology was applied to the syntheses of $(R)$-rolipram and $(R)$-baclofen which are respectively a potent inhibitor of the cardiac cyclic AMP phosphodiesterase and a GABA agonist. As shown in Scheme 23 (first equation), $(R)$-rolipram was directly obtained with both high yield (92\%) and enantioselectivity $(92 \% e e)$ from the domino reaction of a $\gamma$-azido olefinic ester prepared in six steps from 2-methoxyphenol. The synthesis of $(R)$-baclofen was achieved through hydrolysis with $6 \mathrm{M} \mathrm{HCl}$ of another domino product (Scheme 23, second equation) also obtained with both high yield (82\%) and enantioselectivity (89\% ee).

In 2007, Kobayashi et al. reported the total synthesis of the natural cytotoxic $C_{2^{-}}$ symmetric cyclic decadepsipeptide onchidin. ${ }^{67}$ The key step of this synthesis was an enantioselective Mannich-type reaction between 2-amino-m-cresol, 5-hexynal and a ketene silyl acetal derived from phenyl propionate which was promoted by a chiral zirconium catalyst derived from a fluorinated $(S)$-BINOL as ligand. As shown in Scheme 24 , this three-component process led to the formation of the corresponding chiral 

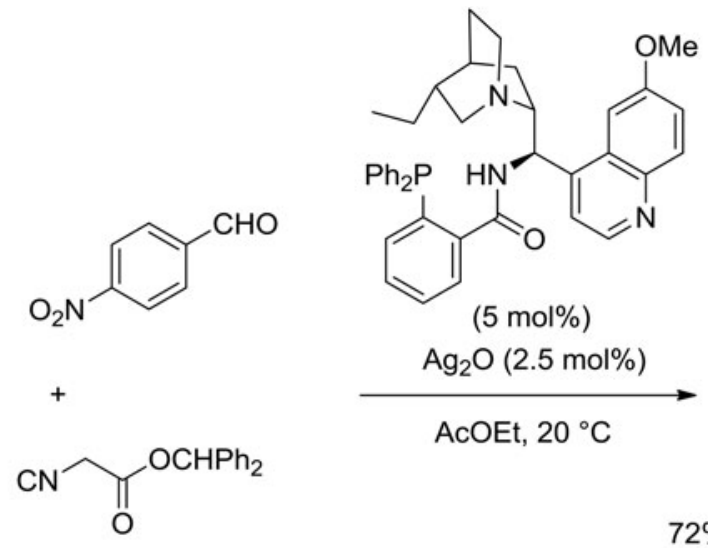

(5 mol\%)

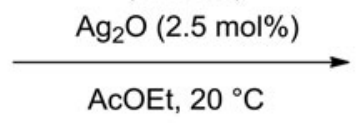

AcOEt, $20^{\circ} \mathrm{C}$

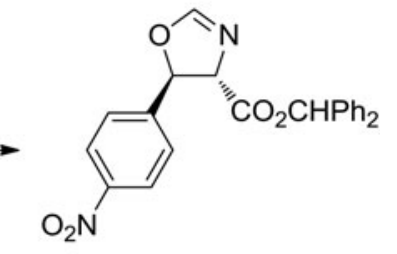

$72 \%$ yield, $82 \%$ de, $89 \%$ ee

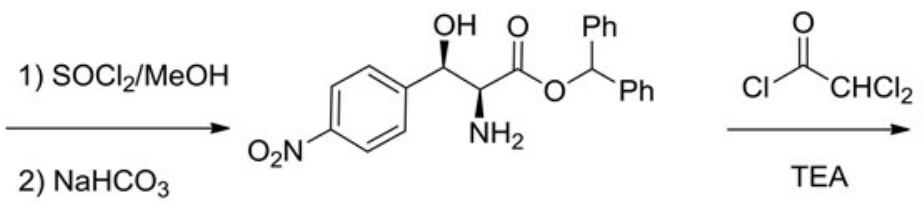

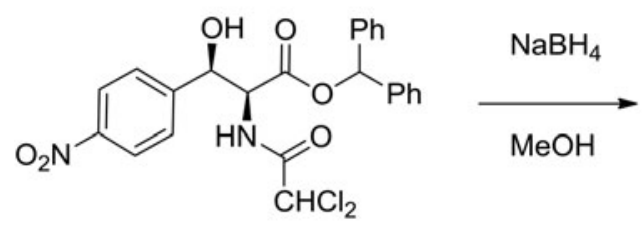<smiles>O=C(N[C@@H](CO)[C@H](O)c1ccc([N+](=O)[O-])cc1)C(Cl)Cl</smiles>

(-)-chloramphenicol

mechanism of the domino aldol/cyclization:
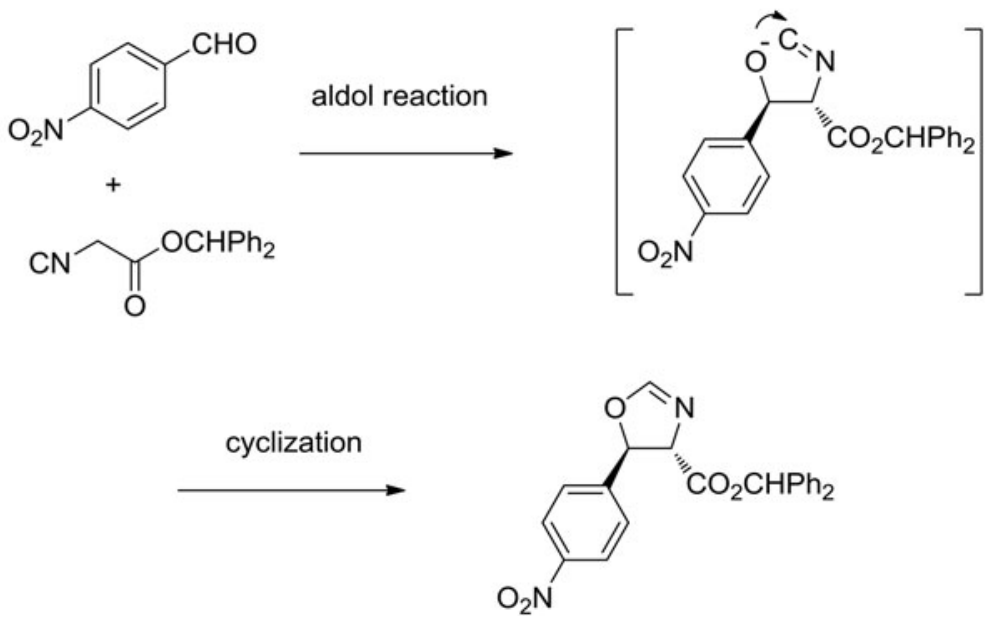

Scheme 25 
Mannich anti-product in both good yield (85\%) and diastereoselectivity (82\% de) combined with excellent enantioselectivity $(96 \% e e)$. Then, this domino product was converted into the corresponding $N$-Boc-protected dipeptide in four steps. The latter was further coupled with the hydrochloride salt of a tridepsipeptide to give the corresponding pentadepsipeptide. This compound was coupled with another pentadepsipeptide to give the corresponding linear decadepsipeptide. Cleavage of the TMS group followed by $N$-Boc deprotection and final macrocyclization afforded onchidin.

In 2016, Dixon et al. reported a novel total synthesis of the antibiotic (-)-chloramphenicol based on an enantioselective silver-catalyzed domino aldol/cyclization reaction. ${ }^{68}$ In this key step, $p$-nitrobenzaldehyde reacted with an isocyano acetate to give the corresponding trans-oxazoline in moderate yield $(72 \%)$ and both good diastereoselectivity $(82 \% \mathrm{de})$ and enantioselectivity $(89 \%$ ee), as illustrated in Scheme 25. This process was promoted at room temperature with a chiral silver catalyst in situ generated from $\operatorname{Ag}_{2} \mathrm{O}$ and a cinchona alkaloid as ligand. The formed chiral domino product was further converted into (-)-chloramphenicol through four supplementary steps, which are detailed in Scheme 25. The ringopening of the domino product using thionyl chloride provided the corresponding amino alcohol which was further acetylated with dichloroacetyl chloride to give the corresponding dichloroacetamide. Finally, the chemoselective reduction of the ester group in this compound with sodium borohydride delivered (-)-chloramphenicol.

\section{Conclusion}

This review collects total asymmetric syntheses of natural and/or biologically important products using enantioselective metal-catalyzed domino reactions as key steps. It shows that these economic one-pot processes have already allowed many important complex molecules to be achieved from simple starting materials. The increasing diversity of these fascinating reactions well reflects that of the metals employed to promote them. For example, various types of chiral palladium catalysts have been applied to promote asymmetric Heck-initiated domino reactions with enantioselectivities of up to $94 \%$ ee which were employed as key steps in total syntheses of different natural and/or bioactive products, such as (-)-xestoquinone, (+)-halenaquinone, (-)-physostigmine and $(+)$-esermethole. Other chiral palladium complexes were also used to promote asymmetric Wacker-initiated domino reactions achieved with up to $96 \%$ ee used as key steps in total syntheses of vitamin E, 4-dehydroxydiversonol and (-)-siccanin. Moreover, another type of palladium-catalyzed domino process, including a domino double allylic alkylation reaction, was employed in the total synthesis of $(+)$-agelastatin, providing enantioselectivities of up to $>97 \%$ ee. Related to the growing interest in green chemistry, domino reactions promoted by green copper catalysts represent a challenge in organic chemistry. In this context, many types of asymmetric domino reactions catalyzed by a variety of chiral copper complexes have been applied as key steps in total syntheses. For example, copper-catalyzed Michael-initiated domino processes achieved with enantioselectivities of 94-98\% ee have allowed the synthesis of important products, such as $\mathrm{PGE}_{1}$ methyl ester, grenadamide and marrubiin. Moreover, total syntheses of A-86929, $(S)-(+)$-coniine and Tamiflu have been based on other enantioselective domino reactions including three-component ones with enantioselectivities of up to 95\% ee. Along with palladium and copper chiral complexes, rhodium chiral catalysts have been applied in different types of domino reactions with $88-91 \%$ ee, constituting the key steps in the total syntheses of 11-deoxy- $\mathrm{PG}_{1 \alpha}$ and CP-293,019. Moreover, the 
use of chiral complexes derived from other metals, such as manganese, cobalt, zirconium and silver, also provided excellent enantioselectivities of up to $96 \%$ ee in different types of domino reactions in the total syntheses of $(+)$-equilenin, $(R)$-baclofen, onchidin and (-)-chloramphenicol. Undoubtedly, many other enantioselective metal-promoted asymmetric domino reactions will be discovered in the near future and further applied as key economic steps in total synthesis.

\section{Abbreviations}

\begin{tabular}{|c|c|}
\hline BINAP & 2,2'-bis(diphenylphosphino)-1,1'-binaphthyl \\
\hline BINOL & 1,1'-bi-2-naphthol \\
\hline $\mathrm{Bn}$ & benzyl \\
\hline Boc & tert-butoxycarbonyl \\
\hline BOXAX & 2,2'-bis(oxazolyl)-1,1'-binaphthyl \\
\hline $\mathrm{Bt}$ & benzotriazol \\
\hline CAN & ceric ammonium nitrate \\
\hline $\mathrm{dba}$ & $(E, E)$-dibenzylideneacetone \\
\hline DBU & 1,8-diazabicyclo[5.4.0]undec-7-ene \\
\hline DDQ & 2,3-dichloro-5,6-dicyano- $p$-benzoquinone \\
\hline de & diastereomeric excess \\
\hline DEAD & diethyl azodicarboxylate \\
\hline DIBAL (DIBAL-H) & diisobutylaluminium hydride \\
\hline DIFLUORPHOS & $\begin{array}{l}5,5^{\prime} \text {-bis(diphenylphosphino)-2,2,2',2'-tetrafluoro-4,4'-bi-1,3- } \\
\text { benzodioxole }\end{array}$ \\
\hline DIPEA & diisopropylethylamine \\
\hline DMAP & 4-(dimethylamino)pyridine \\
\hline DMDO & dimethyl dioxirane \\
\hline DMF & $N, N$-dimethylformamide \\
\hline EDC & 1-ethyl-3-(3-dimethylaminopropyl)carbodiimide hydrochloride \\
\hline ee & enantiomeric excess \\
\hline GABA & $\gamma$-aminobutyric acid \\
\hline Hex & hexyl \\
\hline HMDS & hexamethyldisilazide \\
\hline LDA & lithium diisopropylamide \\
\hline MOM & methoxymethyl \\
\hline NBS & $N$-bromosuccinimide \\
\hline NMI & N-methylimidazole \\
\hline Ms & mesyl \\
\hline M.S. & molecular sieves \\
\hline NBS & $N$-bromosuccinimide \\
\hline NMI & $N$-methylimidazole \\
\hline Ns & nosyl (4-nitrobenzene sulfonyl) \\
\hline Phox & phosphinooxazoline \\
\hline PINAP & $\begin{array}{l}\text { 4-[2-(diphenylphosphino)-1-naphthalenyl]-N-[1-phenylethyl]-1- } \\
\text { phthalazinamine }\end{array}$ \\
\hline PMP & $1,2,2,6,6$-pentamethylpiperidine \\
\hline QUINAP & 1-(2-diphenylphosphino-1-naphthyl)isoquinoline \\
\hline r.t. & room temperature \\
\hline SES & $\beta$-trimethylsilylethanesulfonyl \\
\hline
\end{tabular}




$\begin{array}{ll}\text { Taniaphos } & \begin{array}{l}\text { [2-diphenylphosphinoferrocenyl](N,N-dimethylamino)(2- } \\ \text { diphenylphosphinophenyl)methane } \\ \text { tetrabutylammonium fluoride }\end{array} \\ \text { TBAF } & \text { tert-butyldiphenylsilyl } \\ \text { TBHP } & \text { tert-butylhydroperoxide } \\ \text { TBS } & \text { tert-butyldimethylsilyl } \\ \text { TCPTTL } & \text { N-tetrachlorophthaloyl-tert-leucinate } \\ \text { TEA } & \text { triethylamine } \\ \text { Tf } & \text { trifluoromethanesulfonyl } \\ \text { TFA } & \text { trifluoroacetic acid } \\ \text { THF } & \text { tetrahydrofuran } \\ \text { TIPS } & \text { triisopropylsilyl } \\ \text { TMG } & \text { 1,1,3,3-tetramethylguanidine } \\ \text { TMS } & \text { trimethylsilyl } \\ \text { Tol } & \text { tolyl } \\ \text { Ts } & \text { 4-toluenesulfonyl (tosyl) } \\ \text { Val } & \text { valine }\end{array}$

1. J. Zhu and H. Bienaymé, Multicomponent Reactions, p. 484, Wiley-VCH, Weinheim, 2005.

2. H. Pellissier, Tetrahedron, 62, 1619 (2006).

3. D. Enders, C. Grondal, and M. R. M. Hüttl, Angew. Chem. Int. Ed., 46, 1570 (2007).

4. G. Guillena, D. J. Ramon, and M. Yus, Tetrahedron: Asymmetry, 18, 693 (2007).

5. C. J. Chapman and C. G. Frost, Synthesis, 1 (2007).

6. A.-N. Alba, X. Companyo, M. Viciano, and R. Rios, Curr. Org. Chem., 13, 1432 (2009).

7. B. B. Touré and D. G. Hall, Chem. Rev., 109, 4439 (2009).

8. C. Grondal, M. Jeanty, and D. Enders, Nature Chemistry, 2, 167 (2010).

9. L. Albrecht, H. Jiang, and K. A. Jørgensen, Angew. Chem. Int. Ed., 50, 8492 (2011).

10. H. Pellissier, Adv. Synth. Catal., 354, 237 (2012).

11. C. De Graaff, E. Ruijter, and R. V. A. Orru, Chem. Soc. Rev., 41, 3969 (2012).

12. H. Clavier and H. Pellissier, Adv. Synth. Catal., 354, 3347 (2012).

13. H. Pellissier, Chem. Rev., 113, 442 (2013).

14. H. Pellissier, Adv. Synth. Catal., 358, 2194 (2016).

15. S. A. Snyder, Science of Synthesis. Applications of Domino Transformations in Organic Synthesis, p. 1284, Thieme Verlag, Stuttgart, 2016.

16. T. Chanda and J. C.-G. Zhao, Adv. Synth. Catal., 360, 2 (2018).

17. L. F. Tietze and U. Beifuss, Angew. Chem. Int. Ed. Engl., 32, 131 (1993).

18. L. F. Tietze, Chem. Rev., 96, 115 (1996).

19. L. F. Tietze, G. Brasche, and K. Gericke, Domino Reactions in Organic Synthesis, p. 631, Wiley-VCH, Weinheim, 2006. 
20. L. F. Tietze, Domino Reactions - Concepts for Efficient Organic Synthesis, p. 648, WileyVCH, Weinheim, 2014.

21. O. Reiser, M. Weber, and A. de Meijere, Angew. Chem. Int. Ed. Engl., 59, 74 (1989).

22. K. Albrecht, O. Reiser, M. Weber, and A. de Meijere, Angew. Chem. Int. Ed. Engl., 28, 1037 (1989).

23. S. P. Watson, G. R. Knox, and N. M. Heron, Tetrahedron Lett., 35, 9763 (1994).

24. R. Grigg, P. Kennewell, A. Teasdale, and V. Sridharan, Tetrahedron Lett., 34, 153 (1993).

25. R. Grigg and V. Sridharan, Tetrahedron Lett., 33, 7965 (1992).

26. G. D. Harris, R. J. Herr, and S. M. Weinreb, J. Org. Chem., 58, 5452 (1993).

27. F. E. Meyer, K. H. Ang, A. G. Steinig, and A. de Meijere, Synlett, 191 (1994).

28. R. F. Heck, J. Am. Chem. Soc., 90, 5518 (1968).

29. M. Oestreich, The Mizoroki - Heck Reaction, p. 587, Wiley, Chichester, 2009.

30. D. Mc Cartney and P. J. Guiry, Chem. Soc. Rev., 40, 5122 (2011).

31. S. P. Maddaford, N. G. Andersen, W. A. Cristofoli, and B. A. Keay, J. Am. Chem. Soc., 118, 10766 (1996).

32. A. Kojima, T. Takemoto, M. Sodeoka, and M. Shibasaki, J. Org. Chem., 61, 4876 (1996).

33. A. Kojima, T. Takemoto, M. Sodeoka, and M. Shibasaki, Synthesis, 581 (1998).

34. A. Pinto, Y. Jia, and L. Neuville, J. Zhu, Chem. Eur. J., 13, 961 (2007).

35. W. Kong, Q. Wang, and J. Zhu, J. Am. Chem. Soc., 137, 16028 (2015).

36. E. Coya, N. Sotomayor, and E. Lete, Adv. Synth. Catal., 357, 3206 (2015).

37. J. Reinhard, Angew. Chem. Int. Ed., 48, 9034 (2009).

38. R. I. McDonald, G. Liu, and S. S. Stahl, Chem. Rev., 111, 2981 (2011).

39. L. F. Tietze, K. M. Sommer, J. Zinngrebe, and F. Stecker, Angew. Chem. Int. Ed., 44, 257 (2005).

40. L. F. Tietze, F. Stecker, J. Zinngrebe, and K. M. Sommer, Chem. Eur. J., 12, 8770 (2006).

41. L. F. Tietze, J. Zinngrebe, D. A. Spiegl, and F. Stecker, Heterocycles, 74, 473 (2007).

42. L. F. Tietze, D. A. Spiegl, F. Stecker, J. Major, C. Raith, and C. Grobe, Chem. Eur. J., 14, 8956 (2008).

43. L. F. Tietze, S. Jackenroll, D. Ganapathy, and J. R. Reiner, Synlett, 27, 96 (2016).

44. B. M. Trost, H. C. Shen, and J. P. Surivet, Angew. Chem. Int. Ed., 42, 3943 (2003).

45. B. M. Trost, G. Dong, Chem. Eur. J., 15, 6910 (2009).

46. L. A. Arnold, R. Naasz, A. J. Minnaard, and B. L. Feringa, J. Am. Chem. Soc., 123, 5841 (2001). L. A. Arnold, R. Naasz, A. J. Minnaard, and B. L. Feringa, J. Org. Chem., 67, 7244 (2002).

47. T. Den Hartog, A. Rudolph, B. Macia, A. J. Minnaard, and B. L. Feringa, J. Am. Chem. Soc., 132, 14349 (2010).

48. M. Cheeseman and S. D. Bull, Synlett, 1119 (2006). 
49. J. Deschamp, T. Hermant, and O. Riant, Tetrahedron, 68, 3457 (2012).

50. L. Mangoni, M. Adinolfi, G. Laonigro, and R. Caputo, Tetrahedron, 28, 611 (1972).

51. S. Hajra and S. Bar, Chem. Commun., 3981 (2011).

52. N. Gommermann and P. Knochel, Chem. Eur. J., 12, 4380 (2006).

53. K. Alagiri, M. Furutachi, K. Yamatsugu, N. Kumagai, T. Watanabe, and M. Shibasaki, J. Org. Chem., 78, 4019 (2013).

54. K. V. Gothelf and K. A. Jorgensen, Chem. Rev., 98, 863 (1998).

55. A. Padwa and S. F. Hornbuckle, Chem. Rev., 91, 263 (1991).

56. A. Padwa, Chem. Soc. Rev., 38, 3072 (2009).

57. N. Shimada, T. Hanari, Y. Kurosaki, K. Takeda, M. Anada, H. Nambu, M. Shiro, and S. Hashimoto, J. Org. Chem., 75, 6039 (2010).

58. N. Shimada, T. Hanari, Y. Kurosaki, M. Anada, H. Nambu, and S. Hashimoto, Tetrahedron Lett., 51, 6572 (2010).

59. T. Arai, H. Sasai, K.-i. Aoe, K. Okamura, T. Date, and M. Shibasaki, Angew. Chem. Int. Ed. Engl., 35, 104 (1996).

60. K.-i. Yamada, T. Arai, H. Sasai, and M. Shibasaki, J. Org. Chem., 63, 3666 (1998).

61. K. Funabashi, H. Ratni, M. Kanai, and M. Shibasaki, J. Am. Chem. Soc., 123, 10784 (2001).

62. E. Ichikawa, M. Suzuki, K. Yabu, M. Albert, M. Kanai, and M. Shibasaki, J. Am. Chem. Soc., 126, 11808 (2004).

63. M. A. Sanner, T. A. Chappie, A. R. Dunaiskis, A. F. Fliri, K. A. Desai, S. H. Zorn, E. R. Jackson, C. G. Johnson, J. M. Morrone, P. A. Seymour, M. J. Majchrzak, W. S. Faraci, J. L. Collins, D. B. Duignan, C. C. Prete, J. S. Lee, and A. Trozzi, Bioorg. Med. Chem. Lett., 8, 725 (1998).

64. H. Nemoto, M. Yoshida, K. Fukumoto, and M. Ihara, Tetrahedron Lett., 40, 907 (1999).

65. M. Yoshida, M. A.-H. Ismail, H. Nemoto, and M. Ihara, J. Chem. Soc., Perkin Trans. I, 2629 (2000).

66. A. S. Paraskar and A. Sudalai, Tetrahedron, 62, 4907 (2006).

67. S. Kobayashi, J. Kobayashi, R. Yazaki, and M. Ueno, Chem. Asian J., 2, 135 (2007).

68. A. Franchino, P. Jakubec, and D. J. Dixon, Org. Biomol. Chem., 14, 93 (2016). 